\title{
The Sistine Mosaics of S. Maria Maggiore in Rome: Christology and Mariology in the Interlude between the Councils of Ephesus and Chalcedon*
}

\begin{abstract}
In the present re-reading of the Sistine mosaics of S. Maria Maggiore, which embraces the Old and New Testament scenes in their totality, it will be argued that the iconography is a visual manifestation of the Christology predominating in the Roman Episcopate during the interlude between the Councils of Ephesus and Chalcedon (AD 431 to 451). The fact that the Old Testament narration opens with the Life of Abraham and concludes, on the opposite wall, with the Battles of Joshua, including a distinct pictorial indication of the position of Rahab, the harlot of Jericho, who became the great-great-grandmother of King David, has led the present author to the suggestion that the lost panels concluding the cycle may have included at least one Davidic scene. Such a scene would have extolled the soteriological meaning of the human nature of Christ, "the Son of David, the Son of Abraham" (Mt 1:1), thoughts expounded by Leo the Great in his Tomus ad Flavianum, which laid the ground for the Chalcedonian Council. By the same token the thesis will be advanced that, on the triumphal arch, the matron in the blue maphorion, who sits on Christ's left side, counterbalancing the Virgin in the Adoration of the Magi scene, may be a personification of the women in the genealogical line of Jesus Christ listed in the Gospel of Matthew (Mt 1:1-16). The two women counterpoised in the Adoration scene would thus exalt and substantiate the Gentile, non-Jewish, contribution to the lineage of Our Saviour. The divine providence expressed through these 'extraneous' links in His ancestry (the key figures of whom were the Gentile women Rahab and Ruth), in the story which led to the Descent of the Logos and the Birth of Christ, may have been the underlying, unifying theme in the vast decoration of the basilica.
\end{abstract}

* I am deeply grateful to prof. Per Jonas Nordhagen at the University of Bergen-Norway, who has critically examined the paper. His contributions in the field of iconography, mosaic technique, and also his detailed knowledge as to the state of preservation and the history of restoration of the Sistine mosaics in S. Maria Maggiore have been of utmost importance during the progress of the present work. I will also thank prof. Gunnar Danbolt at the University of Bergen for his examination of the paper. 


\section{A new key}

As is well-known, the fifth-century mosaics in S. Maria Maggiore comprise a cycle of Old Testament scenes at the clerestory level of the nave. The lives of the Patriarchs, the flight out of Egypt and the conquest of the Promised Land are described in them, while the story of Christ's Advent and scenes from His Childhood are represented on the triumphal arch.

The architectural and decorative campaign of Sixtus III (AD 432-440) at S. Maria Maggiore postdates by one year the Council of Ephesus and the dogma of Theotokos. This has led to the assumption that the iconography of the programme reflects the Ephesian dogma of Theotokos. ${ }^{1}$ The Ephesian reading of the programme, which builds primarily on the New Testament Childhood cycle on the triumphal arch, with its striking details such as the Virgin's golden trabea, has however been questioned by some scholars. ${ }^{2}$ In a recent monograph on S. Maria Maggiore, V. Saxer maintains that the Marian content of the Sistine mosaics is secondary to their christological meaning; further, he denies there is any particular nexus between the Ephesian dogma and these cycles. ${ }^{3}$ Saxer may rightly object to the thesis that the motifs are an explicit manifestation of the dogma of Theotokos, or that they reflect what one may call the 'official iconography' invented to celebrate this dogma. Still, his conclusions, which state categorically that all Marian allusions are absent from the Old Testament cycles of the nave (toute allusion mariale est absente du cycle vétérotestametaire de la nef), ${ }^{4}$ seem overstated. A number of objections can be made to them. Leads drawn from the series of Old Testament panels in the nave of the church, often overlooked as to their real significance, support my alternative reading.

The epistemological as well as methodological risks connected with the decoding of late-antique and early medieval iconography are well known; they seriously delimit our prospects of exegesis and theory making. The reading of the iconography that will be presented here is no exception. Yet, due to its richness of detail, this singular monument calls for further reflection on its levels of meaning. Accordingly, the Marian question will here be re-investigated through

1. Wilpert 1916, 473, n. 1; Wilpert 1931, 197-213; Wellen 1961, 93-94. For a discussion of the Ephesian question; see: Brenk 1975, 47-49.

2. See for instance: Grabar 1968, 47. Regarding the golden vestment of the Virgin, Brenk [Brenk 1975, 52] holds that "Die fürstliche Kleidung der Maria muss [...] nicht mit dem Ephesium erklärt werden." He thinks the royal costume of the Virgin may be a phenomenon that corresponds to the representation of Christ as Emperor: "Es wäre also die kaiserliche Triumphalikonographie für den in Frage stehenden Vorgang verantwortlich zu machen." In Christian devotional and poetical literature, moreover, the Virgin has been described in terms that fit well to the Regina typology found in iconography: "Die Darstellung Maria Regina ist kein Hauptthema der Christlichen Ikonographie geworden, während dieser Titel gerade in der erbaulichen und poetischen Literatur des Mittelalters eine bedeutsame Rolle spielen sollte."

3. Saxer 2003, 53.

4. Ibid. 
an analysis of the complete iconographical setting of the fifth-century basilica. What do the mosaics of S. Maria Maggiore, in their totality, tell us about the Mariology and Christology of the Roman Church in the years following the Ephesian Council?

A suitable point of departure is the often-discussed scene on the triumphal arch of the church, the Adoration of the Magi (Fig. 2). As pointed out by many, the scene in the form here found has no known parallel in the recorded iconography: the Child, who sits on a huge throne, is flanked by two female figures, while the Magi, two to one side and one to the other, are presenting their gifts. While there is near consensus among scholars that the woman dressed in gold on Christ's right side is the Virgin, the identification of the mysterious matron in a dark blue maphorion on the Child's left side is a subject of unending discussion by scholars. Several have identified the two women respectively as personifications of the ecclesia ex gentibus and the ecclesia ex circumsione ${ }^{5}$. In the present re-investigation of the iconography of the basilica the premises for a new attribution of the woman clad in the maphorion will be discussed. It will be argued she is a personification of the Old Testament women who miraculously transmitted the seed of Abraham until the begetting of David; hence she is a mother in the genealogy of David and a forebear of Christ.

My thesis on the key role played by David and his lineage in this iconographical system draws on an interpretation offered by J. D. Sieger (1987). ${ }^{6}$ In her analysis of the pictorial programme, she leans on Leo the Great's Sermons on the Nativity, and argues that there is, in fact, a Davidic bias in the imagery. This bias, she asserts, transpires even in the representation of the Virgin in her spectacular royal garments: "the golden trabea shows that this woman - in the words of Leo the Great - is 'from the stock of Jesse and David', whose offspring is the fruit or flower of that line [Leo: Sermo XXIV, 1]". The figure of the Virgin is essential to Leo's theology of the Word made Flesh; and according to Sieger, this notion would seem to be manifestly reflected in the iconography on the triumphal arch.

An interpretation of this kind invites a re-reading of the entire iconographical system of the basilica in the light of post-Ephesian Christology and Mariology. Since in a complex iconographical setting a single motif should always be considered within the context of the whole pictorial system, our investigation must embrace the whole ensemble of the often-visited scenes from the Old and the New Testament in the basilica. ${ }^{7}$

5. For an overview on the research history concerning the identification of these women: infra.

6. Sieger 1987, 83-91.
7. The panels and individual scenes are described in detail in: Wilpert 1916; Brenk 1975; Wilpert \& Schumacher 1976. 


\section{The pictorial cycles}

\section{Triumphal arch}

The triumphal arch is divided into four horizontal registers (Fig. 1). The scenes of the Annunciation and Adoration of the Magi will especially be central in the present discussion; both are located on the left side of the $\operatorname{arch}^{8}{ }^{8}$ In the Annunciation (upper zone) the Virgin is represented in the act of spinning the purple thread as described in the apocryphal Protoevangelium of James (Fig. 3). In this scene, as in all the other episodes on the arch, the Virgin is clad in golden vestments and wears a crown and a diadem. ${ }^{9}$ The following scene, the Adoration of the Magi, which is found in the zone immediately below, has a form unparalleled in the history of Christian iconography: the Child on the throne is flanked by two women, and is approached by the Magi - two on the left side of Christ and one on his right side - who present their gifts, while four angels with their hands raised in adoration are standing behind the throne. Since the woman

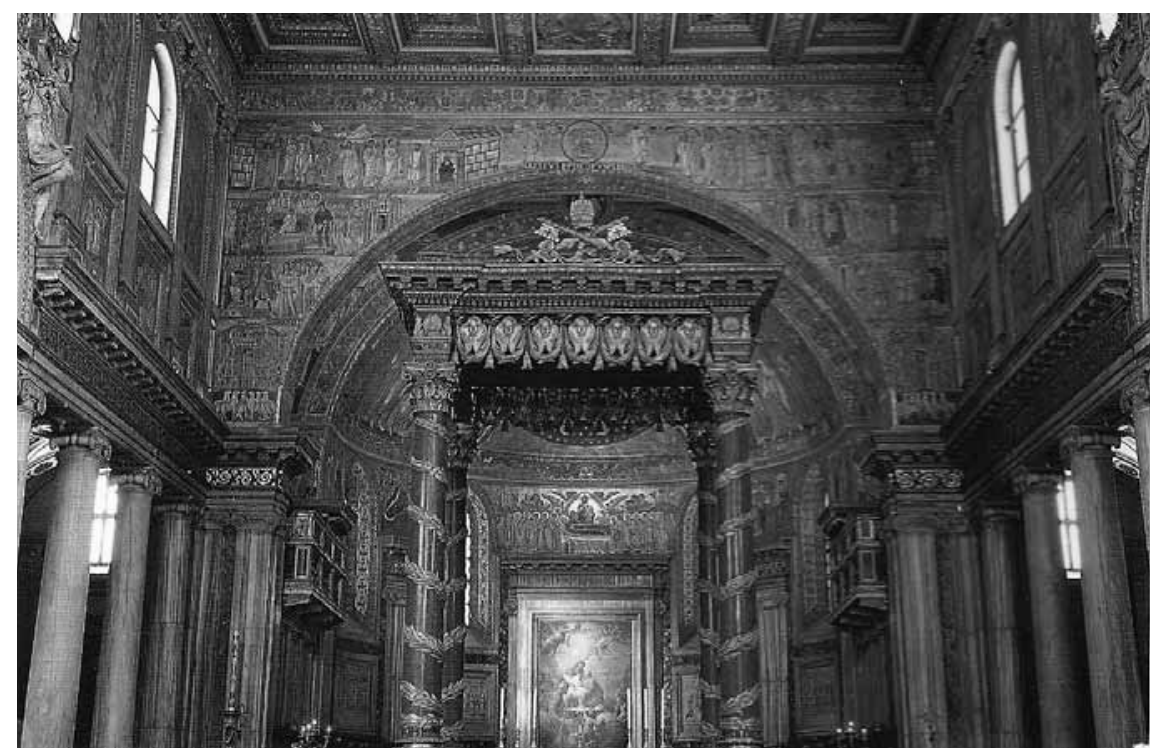

FIG. 1 - Santa Maria Maggiore, nave. View towards apse.

8. The following analysis will be concerned with zones on the triumphal arch that have not been seriously altered by restoration. A survey of the restorations of the triumphal arch mosaics is given by Nordhagen 1983, 323-324. The description that follows of the Childhood scenes on the arch is based on the authentic and unchanged mosaic surface as it appears in the modern photographic coverage checked against Wilpert's plates of the monument in its unrestored state.

9. A well-known parallel to this otherwise wholly atypical dress is seen in the fifth-century ivory diptych of Milan; See: Volbach 1958, Abb. 100. 
to the left is wearing golden vestments, as does the Virgin in the Annunciation scene above, she almost certainly has to be identified with the Virgin Mary. ${ }^{10}$ Yet, the woman on the other side of the throne, clad in a matron's blue maphorion, is the one whose dress most correctly corresponds to the iconographical rules laid down for the representation of the Virgin. This crux is at the centre of the debate, as also of the present study.

In the third (lower) register on this side of the arch there follows a representation of the Massacre of the Innocents, and beneath it, the City of Jerusalem with the Apostle Lambs at the gates. The Presentation in the Temple is represented in the upper zone, right half. ${ }^{11}$ The Virgin Mary, with the Child in her arms, moves towards the right, where an elderly man and woman (usually interpreted as the prophetess Anna and Joseph) are portrayed in a dextrarum iunctio scene, while an angel holds the man's other hand in confirmation of the act (dextrarum iunctio) being performed here. To the right we can see the front of a temple, and twelve old men turning towards the Virgin and Child. While eleven of the men are longhaired and bearded, the foremost (usually interpreted as Simeon) with short grey hair holds his covered hands outstretched towards the Virgin and Child. To the extreme right we see four Jews and an angel addressing someone lying on the ground, interpreted as the announcement to Joseph, asking him to take the Mother and Child and flee into Egypt (Mt 2:13).

As first remarked by N.P. Kondakov (1886), the scene in the zone below is commonly interpreted as the Holy Family at the gate of the city of Sotinen-Hermopolis in Egypt, an episode drawn from the apocryphal gospel of Pseudo-Matthew. ${ }^{12}$ In this scene we see the Governor Aphrodisius accompanied by a bareshouldered older man with long hair, probably a philosopher, as well as a group

10. S. Spain [Spain 1979, 518-540], however, in developing her general thesis about an underlying nexus between Sarah and Mary, argues unconvincingly that the woman in gold is Sarah (below: n. 34).

11. An exception from the common interpretation of this scene as the Presentation is that of Spain [S. Spain 1979, 535], who maintains that the scene represents the encounter between Sarah, holding the Child in her arms, and Joseph and the Virgin: "[...] Mary appears in a group comprising the woman in gold, a middle-aged man in a short tunic and orange mantle, an angel, and an elderly man with white hair and covered hands. The gesture of Mary identifies the man to her right, for the gesture is the dextrarum iunctio, the joining of hands in betrothal. Thus what is taking place here is not the Presentation of Christ but the Betrothal of Mary and Joseph in which an angel plays the part of the priest." On Spain's dubious interpretations of the motifs on the triumphal arch: see n. 34 .

12. This suggestion, based on Pseudo-Matthew (Ch. 22 - 24), stating that the Holy Family fleeing from Herod came to the region of Hermopolis, and entered an Egyptian city called Sotinen, was first made by Kondakov [Kondakov 1886, 105] and by de Waal [de Waal 1887, 187-89]; the thesis has been supported by Brenk [Brenk 1975, 27-30]. Spain [Spain 1979, 519-521] has objected to the purported influence from the Pseudo-Matthew for the reason that the availability of this apocrypha in the fifth century is doubtful. In my view, however, it seems reasonable to assume that fragments of the PseudoMatthew narration may have existed, at least in oral tradition, before the earliest known manuscript of the apocrypha. 


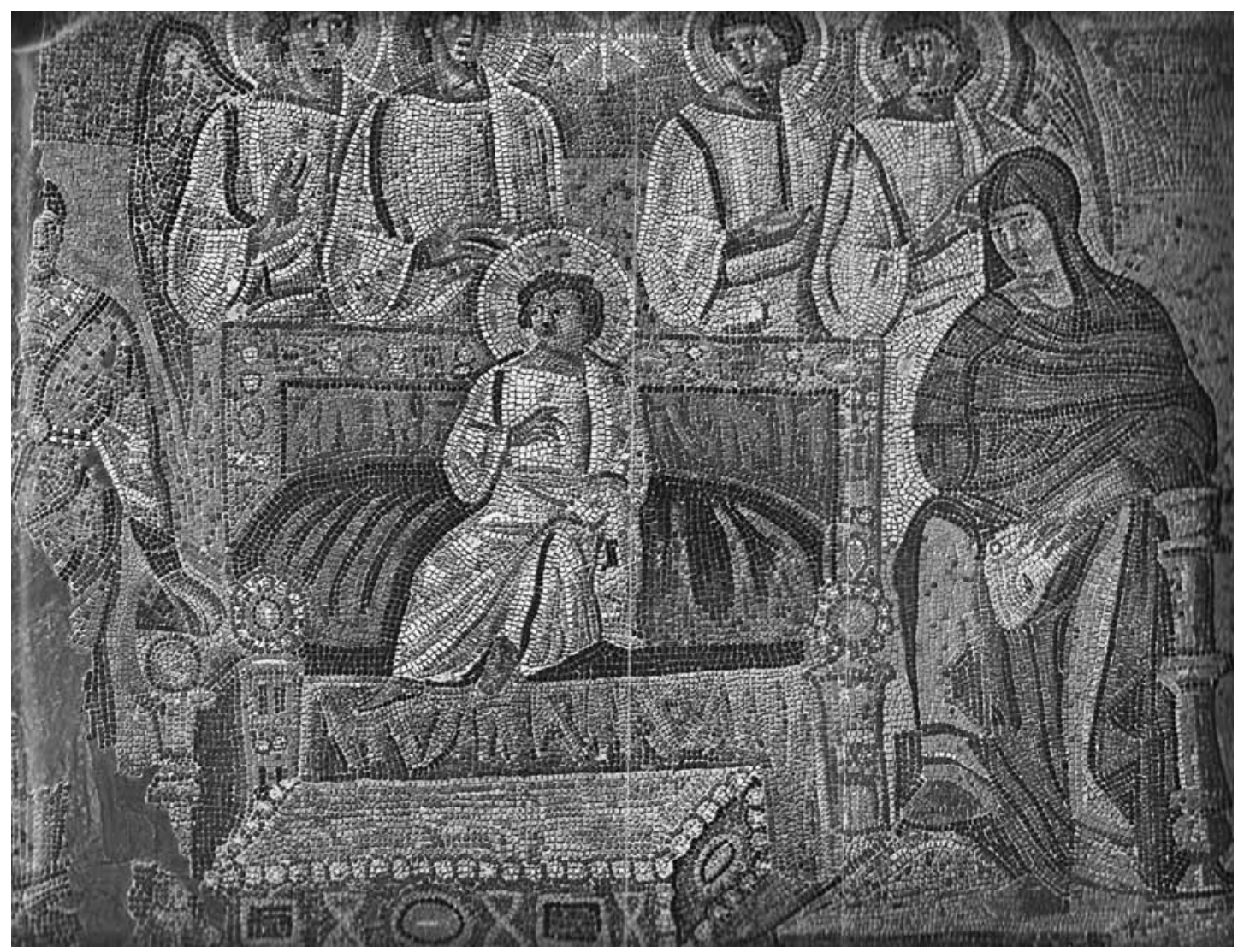

FIg. 2 - Santa Maria Maggiore, triumphal arch: The Adoration of the Magi (after J. Wilpert - W. Schumacher 1976).

of men, who, leaving the city of Sotinen, receive the Holy Family outside the city gates. Mary, Joseph and Christ, accompanied by three angels, are shown to the right in the scene; the meeting outside the city wall is interpreted as a sign of an honourable reception, meant to match the Magi's homage on the other half of the arch. In the zone below we see the Magi before Herod. Beneath this scene is the city of Bethlehem with Apostle Lambs. The empty throne, on which lies the scroll with the seven seals, is represented at the centre of the triumphal arch. The two Apostle Princes, as well as the four living creatures (Rev 4:6), flank the throne. Beneath it runs the inscription: XYSTUS EPISCOPUS PLEBI DEI (Sixtus, Bishop of the People of God).

\section{The Old Testament cycles of the nave}

Left side of the nave (for the observer facing the apse): the cycle, which begins on the wall next to the triumphal arch, embraces the lives of the Patriarchs Abraham, Isaac and Jacob. It commences with [1] the encounter between Abraham 


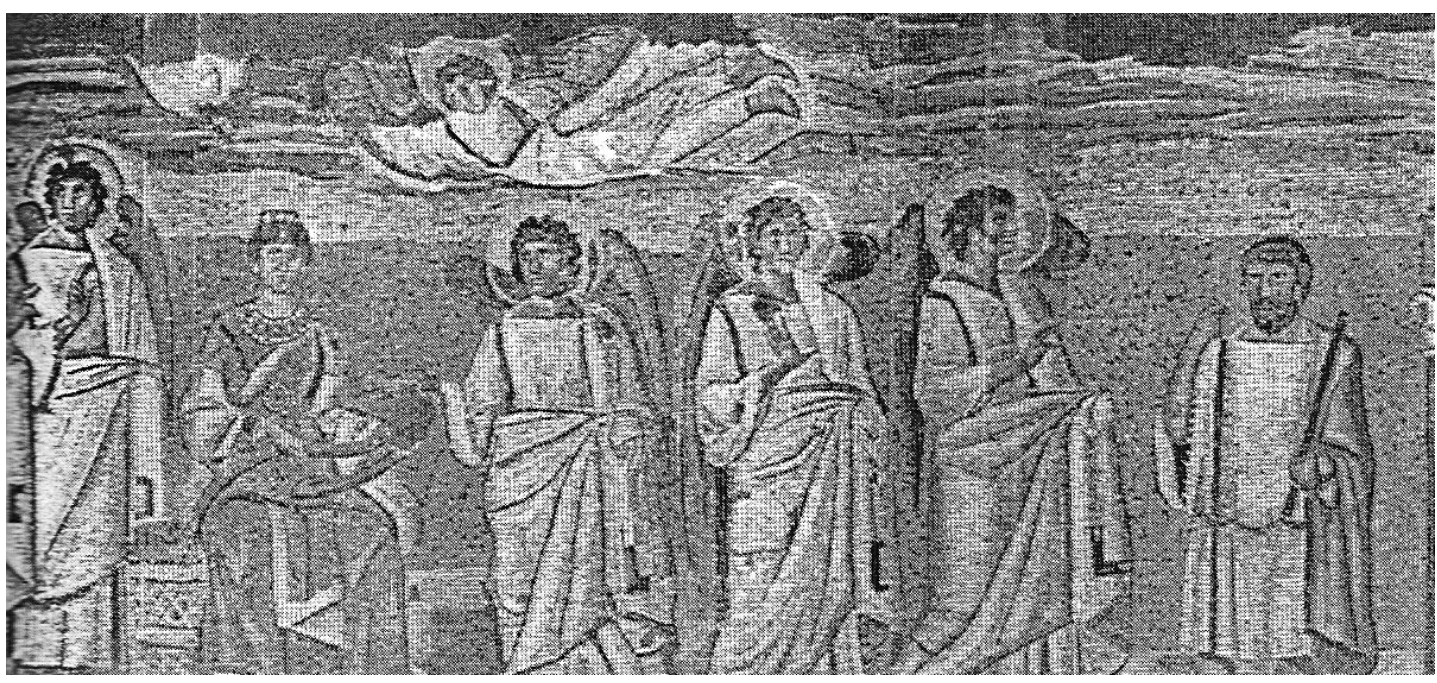

Fig. 3 - Santa Maria Maggiore, triumphal arch. The Annunciation (after J. Wilpert - W. Schumacher 1976).

and Melchizedek (Gen 14:17), then follows [2] the scene with the Hospitality of Abraham (Gen 18) (Figs. 9, 4), and [3] the Separation of Abraham and Lot (Gen 13:11f). The next three panels [4-6] were lost during the construction of the Cappella Paolina. Nevertheless, it has been assumed ${ }^{13}$ that one of these scenes represented the Sacrifice of Isaac (Gen 22). Five panels [9-13] that undoubtedly derive from the Sistine workshop describe Jacob at the House of Laban (Gen 29), where Laban's daughters Rachel and Leah retain a central position in the visual narrative; they are respectively portrayed in orange-red and blue-green vestments (Fig. 6). ${ }^{14}$ The last two fifth-century panels (unrestored) that still exist in this series of scenes drawn from Genesis [17-18] represent the story of Shechem and Dinah (Gen 34).

Right side of the nave: the first [1] panel in the Exodus cycle is lost. The next [2] contains two scenes from the Childhood of Moses (above, Moses as a child and Pharaoh's daughter; below, Moses as a child in disputation with the wise men of Egypt [Philo of Alexandria, De Vita Mosis: 21-24; Acts 7:22]). It should be noted that some of the wise men are dressed exactly as the 'philosopher'

13. Brenk 1975, 62.

14. Our conception of Leah in the iconographical system of S. Maria Maggiore depends on whether we agree with Brenk [Brenk 1975, 109; 117-119], who identifies the woman with a cap and a dull blue palla in scenes 9-11 (left wall) as Leah, or with Wilpert [Wilpert \& Schumacher 1976, 310-311], who identifies her instead as the wife of Laban.
The present author adheres to Brenk's position. The reason is that Rachel and Leah both held key positions in the history of salvation, which seems to be reflected by the location of these women in the panels, where they either appear together in red-orange and blue vestments respectively, or, alternatively, are juxtaposed, thus underlining the different roles played by the two sisters. 
who accompanies Aphrodisius in the reception of the Holy Family at SotinenHermopolis (triumphal arch, right side). The next panel shows, above, the Wedding of Moses and Zipporah (Ex 2:21), and, below, a pastoral scene describing the theophany of God in the Burning Bush (Ex 3:1ff.). The three following scenes represented [4] the meeting between Moses and Aaron (Ex 4, 27)/Moses and Aaron before Pharao (Ex 5, 1-5), followed by [5] the institution of the Pasha-Offerings (Ex 12, 1-27)/the Land flowing of milk and honey (Ex 13, 5), and the Sacrifice of the firstborn (Ex 13, 11-16). The next scene [7] is the Crossing of the Red Sea (Ex 14, 15ff.). The Exodus cycle continues with the story of Joshua (Num 14, Deut $31 \& 34$ and Jos 2, 3, 5, 6 and 10). It is concluded with scenes describing the Crossing of Jordan, and the Fall of Jericho [13-15] (Fig. 5), [17] Joshua's Victory over the five Kings of the Amorites (Jos 10, 6ff.), [18] the Sun and the Moon standing still over Gibeon (Fig. 8) (Jos 10:12ff.), and [19] the Kings of the Amorites led forth to Joshua (Jos 11). The last three panels $[20,21,22]$ are lost. A suggestion as to what they may have contained can be drawn on the basis of the discussion that follows.

\section{The woman in the blue maphorion}

As noted above, the woman dressed in the blue maphorion, who sits on Christ's left side in the Adoration of the Magi scene (Fig. 2), has aroused much discussion. The Child on the throne is flanked by the two female figures already described above, while the Magi, entering through the city gates of Bethlehem, present their gifts. Although there is near consensus among scholars that the woman dressed in gold to the right of Christ is the Virgin, the identification of the mysterious matron in dark blue maphorion on the Child's left side is still a matter of much dispute. ${ }^{15}$ She has been variously identified as the mother of the Virgin, Anna ${ }^{16}$, as a nurse ${ }^{17}$, as a Sibyl ${ }^{18}$ (a theory recently restated by R. Warland $)^{19}$, or as the personification of the ecclesia ex circumcisione ${ }^{20}$, of the ecclesia ex gentibus ${ }^{21}$, or of the Synagogue. ${ }^{22}$ A. Grabar (1936), in his influential study, argued that Mary be identified with the woman dressed in gold on Christ's right; that she also personifies the New Testament; and that the matron clad in the blue maphorion must therefore signify the Old Testament, either as a personification or as the Prophetess Anna, who is represented with the same kind

15. For a comprehensive survey of the research history on this motif until 1991: see A. Ahlquist, 1991, 109-132.

16. Wilpert 1917, 486-487; Schuchert 1954, 145.

17. Garrucci 1873-1881, 17-18.

18. Thérel 1962, 153-171; Marini Clarelli, 1996, 323344.

19. Cf. infra, p. 41. Warland here follows a similar line of argument as Grabar in suggesting that the elders in the Presentation scene are the elders of the Roman people, greeting the Child. [cf. also Schubert, 1995, 83-84]. On this basis Warland infers that the woman in the maphorion in the Adoration scene must be the Roman Sibyl.

20. Richter-Taylor, 1904, 331-337; Berchem-Clouzot 1954, 51.

21. de Bruine 1936, 253.

22. de Rossi 1899, 33. 


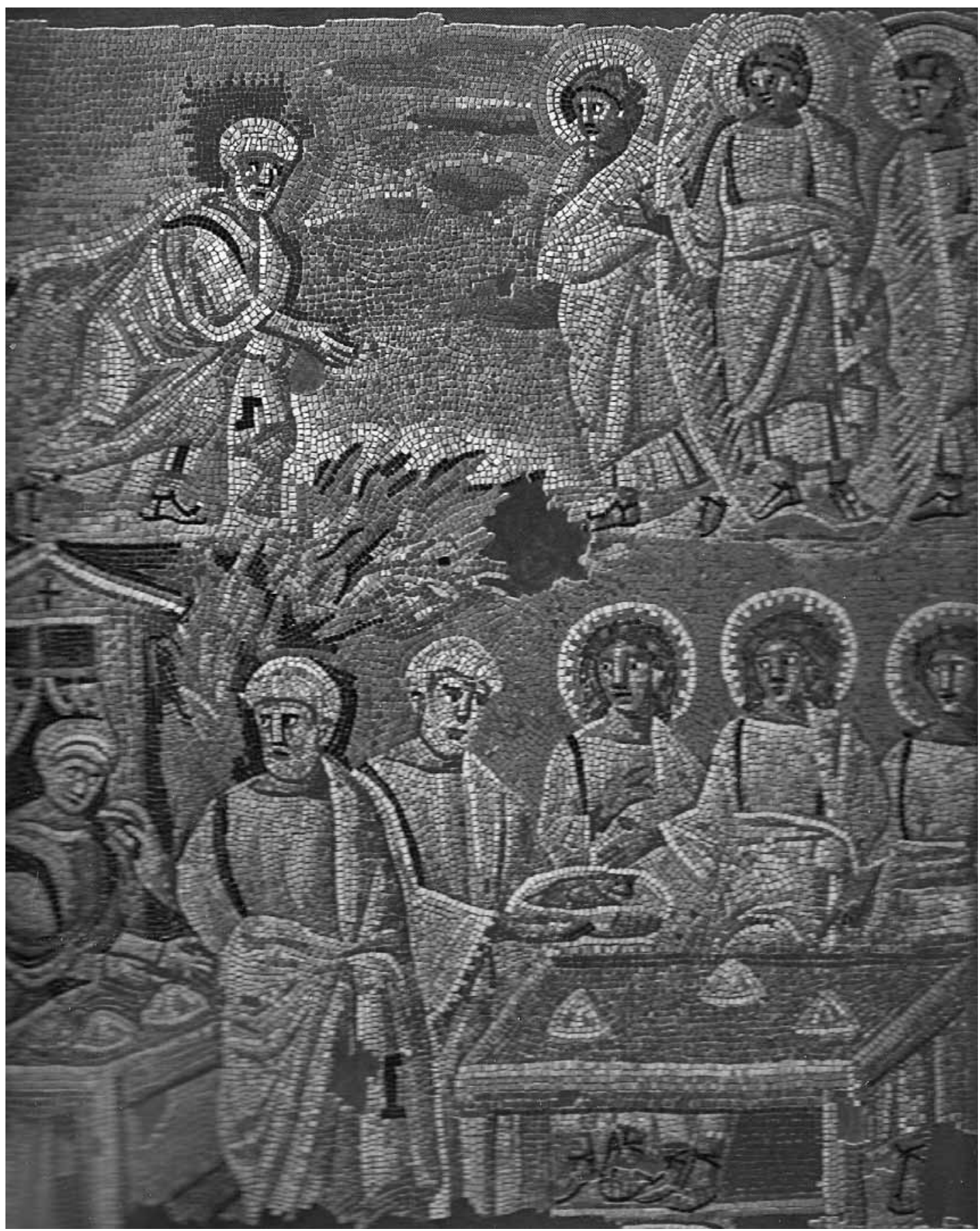

FIG. 4 - Santa Maria Maggiore, Genesis cycle of the nave: Panel 2 (left wall), The Hospitality of Abraham (after J. Wilpert - W. Schumacher 1976). 


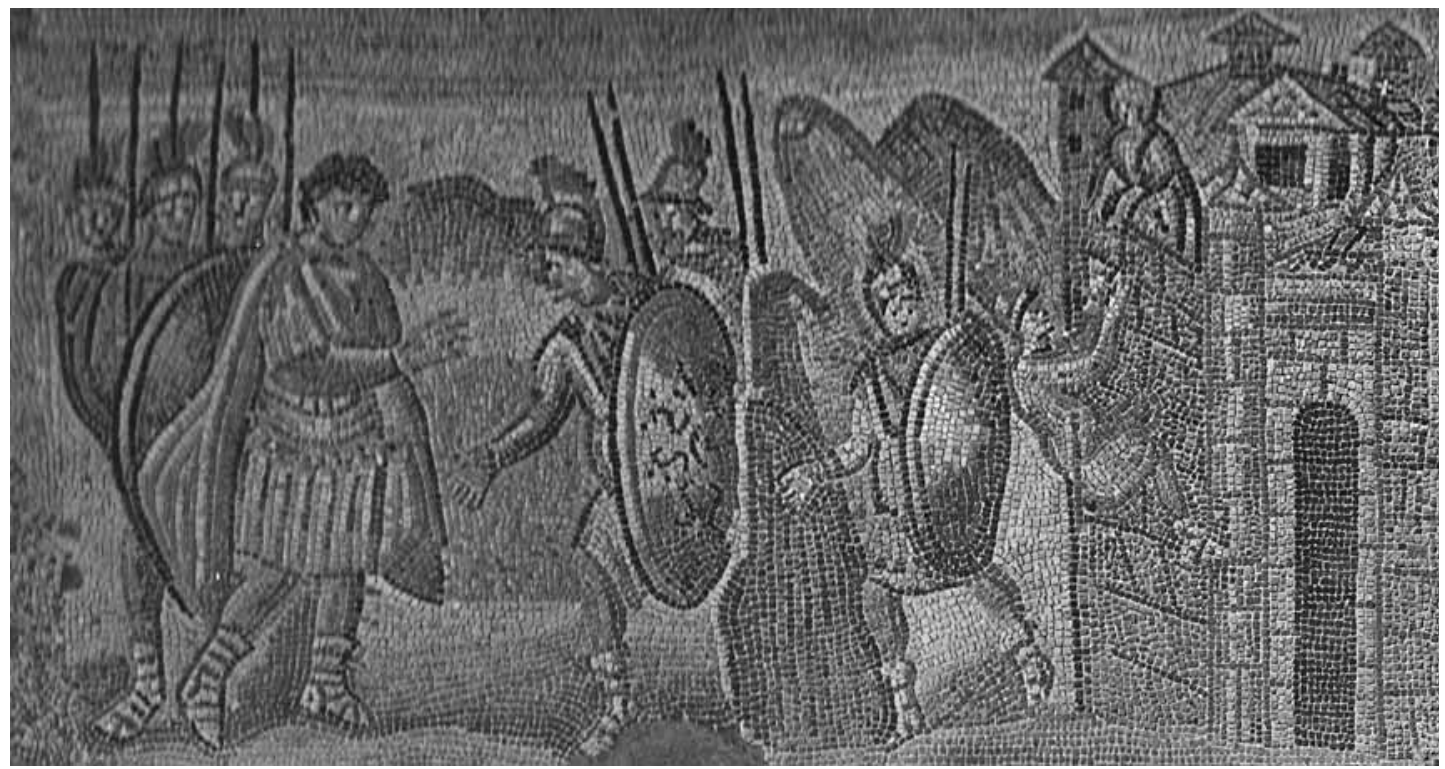

FIg. 5 - Santa Maria Maggiore, Joshua cycle of the nave: Panel 14 (right wall), The Return of the Spies from Jericho, with Rahab on the City Walls (after J. Wilpert- W.Schumacher 1976).

of maphorion in the Presentation scene. ${ }^{23}$ The woman has also been interpreted as the midwife Salome (from the Protoevangelium of James). ${ }^{24}$

In the revised edition of Wilpert's Die Römische Mosaiken und Malereien, W. N. Schumacher (1976) sees the complex Adoration scene as a reflection of an iconographical scheme deriving from imperial monuments: according to Schumacher, the two women are, respectively, the Virgin and an Old Testament Mother of the People of Israel, presumably Rachel; however, they also function as representations, or personifications, of the two Churches: "mit der Matrone wird eine der alttestamentlichen Mütter des Volkes Israel - vermutlich Rahel gemeint sein. Zugleich kann sie aber auch die Ecclesia ex gentibus darstellen." 25 The thesis that she is Rachel is also supported by P. Künzle. ${ }^{26}$ Those who see a personification of the Ecclesia ex gentibus in the matron dressed in blue include Brenk (1975). ${ }^{27}$ In his illuminating analysis of the total iconographical setting of the basilica, he has suggested that its Old Testament cycles conform to the Time of the Patriarchs and the Time of the Law, corresponding to the Pauline division of history in the Epistles to the Galatians and to the Romans (in Gal 3:6-29 and Rom 3:21-31). ${ }^{28}$ The figure of Abraham is essential for this interpre-

23. Grabar 1936, 228.

24. Jastrzebowska, 1992.

26. Künzle 1961/62, 171-176.

25. Wilpert \& Schumacher 1976, 317; cf. Deckers 1982, 20-32.

27. Brenk 1975, 27.

28. Brenk 1975, 112. 
tation: by the Lord's covenant Abraham was made the ancestor of a lineage as numberless as the stars of heaven or the sand on the seashore (Gen 22:17a; cf. Gen 15:5 \& 26:4).

According to Brenk, in the iconography of S. Maria Maggiore, Sarah, Rebecca and Rachel in the Old Testament scenes appear as pre-figurations of the Church. He shows that the textual basis for an ecclesiological comprehension of the motifs is provided by the writings of the Church Fathers. Brenk refers, among others, to Jerome: in Sarah, who prepared the three cakes for the visitors in Mamre (Gen 18:6), Jerome saw a pre-figuration of the Ecclesia; in Ambrosian exegesis, too, Sarah prefigures the Ecclesia, here the Ecclesia ex gentibus. ${ }^{29}$ Moreover, Brenk adduces the Pauline separation among the descendents of Abraham between the children of the promise and the children of the flesh (Rom 9:7-9) as one leading principle behind the organization of the iconographical system in S. Maria Maggiore. As an example Brenk points to the panel describing the separation of Abraham and Lot (panel 3, left side): "Die Szene illustriert sowohl den Vorgang der Trennung als auch den heilsgeschichtlichen Kontrast zwischen den Kindern Abrahams und Lots. Isaak ist der Mann der Verheissung, wogegen die Töchter Lots die Synagoge verbildlichen könnten [Brenk refers here to Irenaeus adv. haer. 4.31]; sie sind nicht Kinder der Verheissung"..$^{30}$ He finds the same principle at work in the representation of Old Testament women such as Rachel (Ecclesia) and Leah (Synagogue). ${ }^{31}$ Brenk also stresses the pre-figurations of Christ that are found in the cycle (Melchizedek, Isaac), and maintains that: "Christus, Ecclesia und Synagoge sind die Oberbegriffe, welche sich bei den italienischen Interpreten des 4. und 5. Jh. als relevant erweisen". ${ }^{32}$

Another interpretation, which deviates somewhat from the most common identification of the two women in the Adoration scene, was proposed by A. Ahlquist (1991), who pointed out that there are two maphorion-clad women on the triumphal arch (in addition to the one in the Adoration there is one in the Presentation scene i.e. the one commonly identified as the prophetess Anna). The ecclesiological meaning, she argues, is expressed through these two women: they should be comprehended as personifications of the two Churches: respectively of the ecclesia ex circumcisione and the ecclesia ex gentibus..$^{33}$ To these readings of the iconography we should lastly add the re-interpretation of the triumphal arch by S. Spain (1979), who categorically excluded the proposition that the woman clad in gold could be the Virgin; in Spain's interpretation this woman is Sarah, Abraham's wife, while the matron in the maphorion must then be Mary.

29. Brenk 1975, 115.

30. Brenk 1975, 116.

31. Brenk 1975, 118.
32. Brenk 1975, 119.

33. See n. 15. 


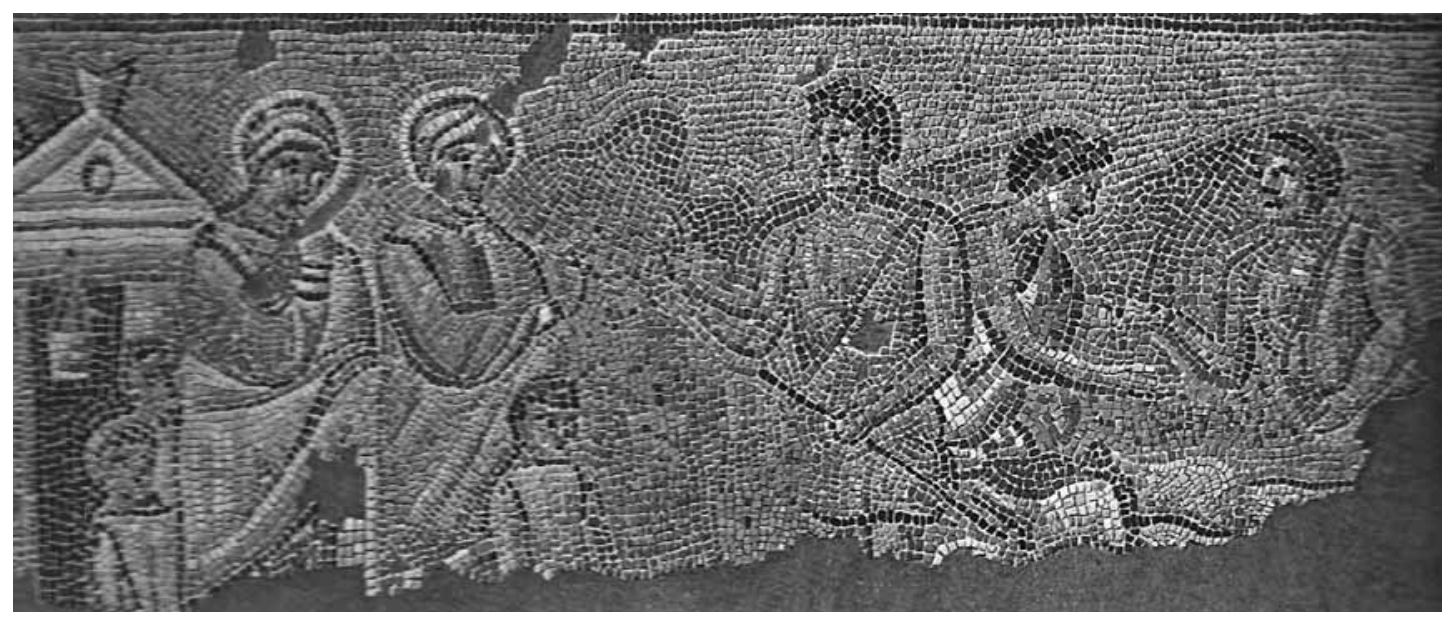

FIg. 6 - Santa Maria Maggiore, Genesis cycle of the nave. Panel 13 (left wall), Jacob with Rachel, Lea and sons (after J. Wilpert - W. Schumacher 1976).

Despite its methodological flaws ${ }^{34}$, her reading contains some valuable observations, as it points to the prominence given to Abraham in the scenes that open the Genesis cycle in the nave.

\section{The Old Testament mothers of the Davidic Messiah}

As a point of departure for my own research into this iconographical system, it seems that a comprehensive re-investigation of the Sistine mosaics would help us to gain an insight into the mechanisms that may have determined the organization of the pictorial cycles. It will be argued that the mysterious matron in the maphorion is a figure typologically closely related to the Virgin Mary herself, thus excluding the notion of her playing a part in a symbolism related solely to the Ecclesia concept. It will be asked, as I have done above, whether this figure could be a personification of the women through whom God multiplied the seed of Abraham. God's promise to Abraham that he would multiply the Patriarch's descendents (Gen 22:17) could, as has been suggested, ${ }^{35}$ be a leading principle in the iconographical system of the Basilica.

34. Spain's identification of the woman in golden vestments as Sarah and the man clad in white tunic (usually interpreted as a representation of Joseph) as Abraham has been dismissed by Nordhagen, for the reason that he considers her observations on the state of preservation of the mosaics as faulty (cf. Nordhagen 1983, 323-324). As to my own reading of Spain's the- sis, I can hardly accept that the woman clad in gold in a scene like the Annunciation, where the Dove and an Angel overshadow the woman, and where her act of spinning perfectly conforms to the story narrated in the Protoevangelium of James, could possibly be Sarah and not the Virgin.

35. Cf. Brenk: above. 
It is remarkable that the scene of the Receiving of the Tablets of the Law at Sinai is omitted from the part of the Old Testament cycle devoted to Moses. ${ }^{36} \mathrm{We}$ find represented, on the other hand, the miracles through which God worked out his plan of salvation for the People of Israel during their wanderings toward the Promised Land. The miracles described in the Old Testament scenes in S. Maria Maggiore are all pre-figurations of the greatest of all mysteries: the katabasis (descent) of the Logos in flesh. Another significant point that should not escape us here regards the prominence accorded in these mosaics to the female figures in the episodes from Genesis as well as in those from Exodus/Joshua. These are women who suffered from barrenness, but who were miraculously transfigured into fertility, or who occupy some other key position in the lineage of Abraham. To the first category belong Sarah, Rebecca and Rachel, who are all included in the Genesis cycle of S. Maria Maggiore (panels, left wall: 2, 7, 9, 10, $11,13,15)$; to the second category belongs Rahab, the harlot who hid the messengers that were sent into Jericho (panels, right wall: 13, 14, 15). According to Matthew 1:5, Rahab's son Boaz was the father of Obed by Ruth, while Obed was the father of Jesse, whose son was King David. ${ }^{37}$ So Rahab stands in the direct lineage of Christ. An interpretation along these lines was already hinted at by Daniela Calcagnini (2002), who in her recent study on the Early Christian mosaics in S. Maria Maggiore stresses that: "queste figure femminili [...] diventano madri per volere divino, partecipano direttamente al progetto di Dio di aiutare il popolo ebraico a conqiustare la terra promessa e, quindi, essere protagonisti della storia della salvezza. [...] Anche Rahab, prostituita di Gerico, [...] acquisisce una importanza [...] [come] antenato di Davide e di Christo". ${ }^{38}$

These women, who lived under the promise given to Abraham (Gen 21:17), hold a key position in the history of salvation: for it was the children of the promise who were counted for the seed of Abraham (Rom 9:7ff.). The miraculous conversion from barrenness into fertility was reiterated in the conception of the Virgin by her barren parents. ${ }^{39}$ The same miracle recurred in Mary's own life. Through the Annunciation, a girl still to reach the age of fertility became pregnant through the conception by the Logos.

36. W. Kemp has, however, remarked that the Canticle of Moses in Deut 31, which is represented in scene $12 \mathrm{a}$ of the Moses cycle, replaces the Sinai scene: "Die Verkündigung dieses 'Gesetzes' und 'Testamentes' ist das Thema des Mosaikfeldes. Es dient auch als Ersatz für die im Zyklus nicht ohne Bedacht ausgesparte Szene der ersten und eigentlichen Gesetzesübergabe, welche mit der Vorstellung von der Gesetzesfreiheit des Christen kollidiert." He points to the Pauline bias of the omission of the Tablets of the Law scene at Sinai: "Wie der Lehrer der Heidenkirche macht sie einen Bogen um das 'Gesetz', welches durch Christus seine Autorität eingebüsst hat, und profiliert statt dessen die 'Glaubensgerechtigkeit' der Patriarchen und der Führer Israels.” Kemp 1994, 169.

37. Ruth 4: 21.

38. Calcagnini 2002, 1931-1932.

39. The Protoevangelium of James describes in detail the suffering of the childless Anna, who would become the Virgin's mother. Anna prayed in despair to God to bless her and listen to her prayer, just as He had previously blessed Sarah and given her a son, Isaac. Then suddenly an angel stood in front of her and proclaimed that God had granted her prayer. 


\section{The scroll}

To return to the Adoration scene on the triumphal arch, there is one particular detail that has so far escaped our attention: the woman in the maphorion holds a scroll in her left hand. What does it signify? As has recently been pointed out by R. Warland, and earlier by M.-L. Thérel and M.V. Marini Clarelli, ${ }^{40}$ this scroll may refer to the sibylline books of Rome. In spite of Warland's rather perceptive analysis of the $\mathrm{arch}^{41}$, alternative paths of investigation will now be explored as the premises for a new interpretation of the scene in terms of [pre-] Chalcedonian Christology. The question, in short, will be posed whether a figure, or personification, associated with the women in the Gentile ancestry of Christ may be an answer to the problem of how to identify the mysterious matron, who appears in the scene in which Mary faces the Magi of Gentile (non-Jewish) stock. The assumption that the scroll represents the Matthew genealogy of Christ ("Son of David son of Abraham" [Mt 1:1; cf. below]) will be particularly appealing in the light of the fact that in the Old Testament panels in the nave the history of salvation can be recognized and followed, step by step through the seed of Abraham until the fall of Jericho, in which Rahab's contribution to this lineage is commemorated (supra). The roads thus opened up for an interpretation along these lines will now be explored; they all concern the genealogy of Christ.

\section{An hermeneutic interlude}

The Ruth hypothesis

It might be postulated that the scroll held by the matron is an attribute identifying her as one of the female scribes of the Old Testament; one of these, Ruth, as listed by Matthew (1:5), also has a particular position in the genealogy of Christ. If we choose to follow this (genealogical) line of argument, the Old Testament cycles themselves may offer some plausible candidates. We remember that the Moses cycle was concluded by scenes from the story of Joshua: the Fall of Jericho, the Sun and the Moon standing still, Joshua's Victory over the five Amorite Kings. The last three panels are lost; nevertheless, the presence of the harlot Rahab in all three of the Jericho scenes has led me to the assumption that the scenes that ended this cycle may have further underlined the particular position of this woman in the genealogy of David (supra). Her role is central in the history of Israel. The scarlet thread that she exposed as a signal in her window (Joshua 2:18; cf. Mary's spinning of the purple thread in the Annunciation scene on the triumphal arch) became a sign of salvation, and not only for the Israelites in Joshua's army: in Christian exegesis the scarlet thread came to symbolize the Blood of Christ. ${ }^{42}$ From Rahab, the lineage passes directly to that central biblical character, Ruth. 
Rahab's son (as noted above) was Boaz, who "begat Obed of Ruth; and Obed begat Jesse", the father of David, the king (Mt 1:6). As we know, the Moabite woman Ruth is the main protagonist of the Book of Ruth, which she allegedly wrote and which is named after her. As a widow she followed her mother-in-law to Bethlehem, where she married Boaz (Ruth 4:13). The fact that she lived in Bethlehem and that she became the great-grandmother of King David makes her central both in typology and in the history of salvation. This key position of Ruth in the genealogy of Jesus raises the possibility that she might be represented in the woman who counterbalances, and at the same time establishes a kind of typological relationship with, the Virgin on Christ's left in the Adoration of the Magi scene, and that the significance of her presence in this particular iconographical setting, blurred as it may be for a modern observer, may have been regarded as self-evident by a contemporary observer familiar with the christological discourses that took place in the second quarter of the fifth century. The most significant point is that a figure of Ruth in the context suggested here would bring home to us the human ancestry of Christ whose descent from the house and lineage of David was underlined in the genealogy of Matthew (I:1-17) (infra). Ruth was a poor widow until Boaz fell in love with her, and history repeated itself - a woman trusting to God in her suffering and childlessness becomes the bearer of a son whose name and work came to occupy a central position in the history of salvation. Particularly significant for our interpretation is the fact that Ruth, being a Moabite woman, was a non-Israelite, hence she was a Gentile. Such an interpretation would suggest that the scroll may symbolize the Book of Ruth, and that the matron, in fact, might be Ruth.

\section{The Rahab hypothesis}

A. Grabar (1936) demonstrated that the intrinsic 'grammar' behind the organisation of figures in some of the scenes on the arch, and particularly in the Adoration of the Magi scene, would seem to rely on prototypes drawn from the orbit of imperial iconography; one such prototype is reflected in the Halberstadt diptych, where personifications of Rome and Constantinople are symmetrically organized, one on each side of the Emperor. ${ }^{43} \mathrm{He}$ also stressed that in imperial iconography the representative scenes show the Emperor enthroned or standing, and that he is accompanied by narrative scenes describing the battles against the barbarian people he has conquered. In scenes with the glorification of the Emperor, groups of barbarians are represented in the act of adoration together with the People of Rome. ${ }^{44}$

Since the Moses and Joshua cycles in S. Maria Maggiore describe the war against the non-Israelite people in a manner that almost mirrors the representation of warfare in pagan imperial art, and since the Fall of Jericho has a central

43. Grabar 1936, 227-228.

44. Grabar 1936, 210, 80 n. 2. 
position in this narrative, the question arises whether the woman in the blue maphorion might not be a personification of the Gentile people, conquered and subjugated in the victorious expansion of Christianity. An interpretation of this kind would suggest that the matron conforms to the figure of Rahab in the three Jericho panels, raising the harlot to an 'hieratic' level, and counterbalancing the Virgin in the Adoration scene of the arch. ${ }^{45}$ This would imply, however, that she should primarily be considered as a general personification of the significant contribution of the Gentiles in the ancestry of Christ. The composition, in other words, could be seen as following the rules of imperial iconography in the way that Grabar suggested. The fact that the Adoration of the Magi scene, in the same register on the right side of the arch, is counterbalanced by the reception of the Holy Family in Egypt underlines that the meaning of this register is the Adoration of Christ by the pagans, by the Gentiles 'conquered' by Christianity. ${ }^{46}$

Synthesis. The theories, briefly outlined here, postulating a typological association of the matron in the Adoration scene with a particular figure of the Bible (Rahab, Ruth), seem to the present author less plausible than the possibility that she may represent a general personification of the Gentiles, and particularly those who miraculously transmitted the seed of Abraham through David to Christ. As we have underlined, the scene is in accordance with the 'grammar' which in imperial iconography signifies submission as well as adoration; here the object of adoration is the Davidic Messiah. The fact that both women represented were mothers is significant here: the Virgin is the Mother of God, the matron is the 'Mother of David'. The christological implications of this notion will be discussed in the paragraphs that follow.

\section{The Christology of the Old Testament cycles in the light of Matthew 1-2}

Since the Genesis cycle in the nave opens with the story of Abraham, and not with Adam and the Genesis per se, it could be argued that the general lay-out of the iconographical system of the Old Testament mosaics in S. Maria Maggiore de-

45. Exegesis on the typological meaning of the harlot Rahab especially flourished in the West (St. Clement of Rome, St. Justin, St. Irenaeus of Lyons), while, in the Alexandrine School, it is solely Origen who expounds the typology of Rahab. This is not the place to provide any comprehensive discussion of all the facets in the Rahab typology; for a thorough examination of the question see J. Daniélou 1960, pp. 244-249. Here it will suffice to note that St. Justin in his Dialogue with Trypho CXI asserted: "And the blood of the Passover, sprinkled on each man's door-posts and lintel, [...] saved those who were in Egypt, so also the blood of Christ will deliver from death those who have believed. [...]
I affirm that $\mathrm{He}$ announced beforehand the future salvation for the human race through the blood of Christ. For the sign of the scarlet thread, which the spies [...] gave to Rahab the harlot $[\ldots]$ manifested the symbol of the blood of Christ [...]." In St. Justin's exegesis "Rahab is a type of sinful humanity, and particularly of the Gentiles" (Daniélou 1960, 248). In Origen's Third Homily [PG XII, 840C] the harlot "becomes a prophet, for she says, I know that the Lord hath given this land to you".

46. Cf. Sieger, p. 88: "the [Egypt] motif is used as a visual metaphor for the capitulation of the pagan powers of this world, importantly for Leo, pagan Rome - to the truth". 


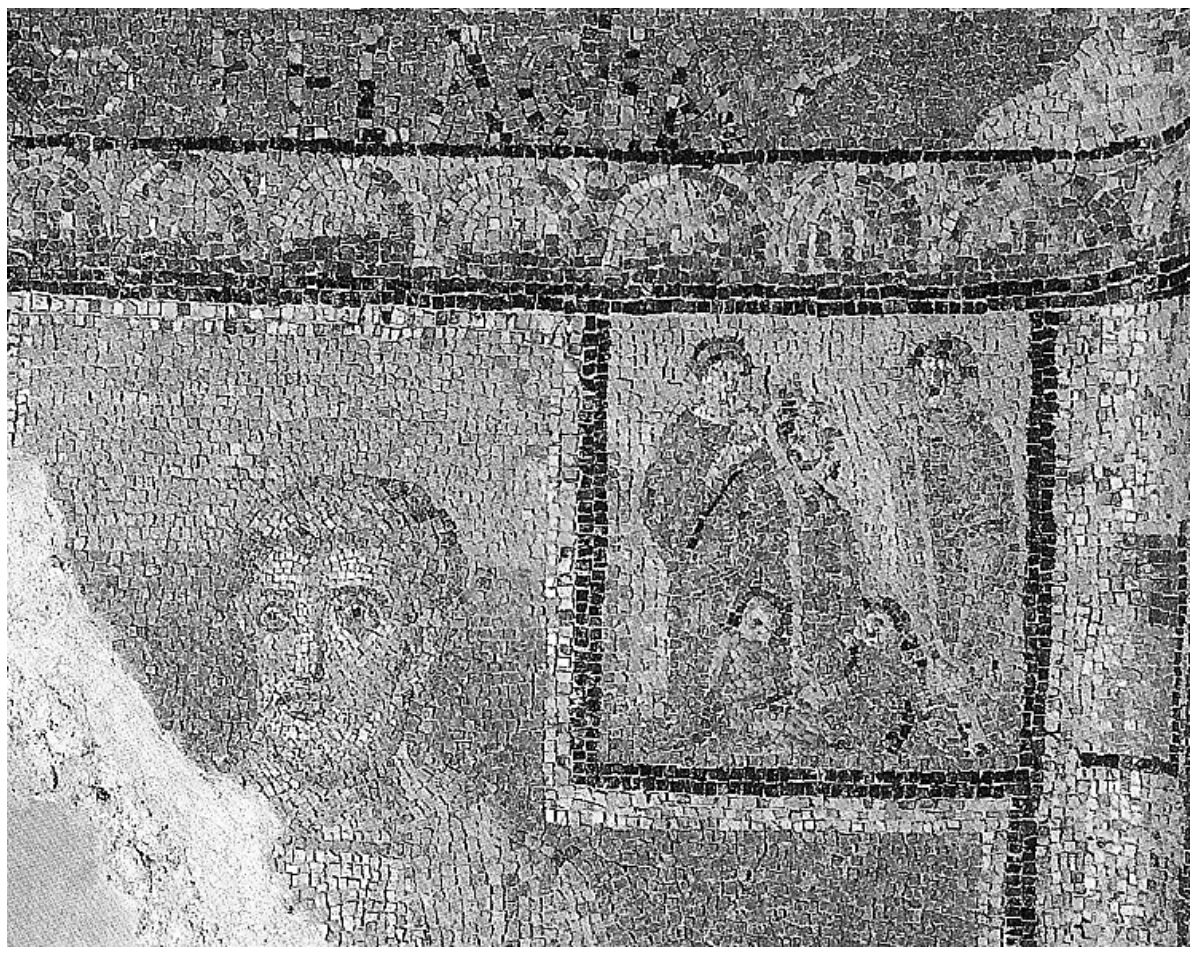

Fig. 7 - Milan. San Lorenzo Maggiore, atrium of S. Aquilinus Chapel. Judah, with a smaller scene showing Judah, Tamar and their twins Pharez and Serah. $5^{\text {th }}$ century.

scribes the genealogical lineage leading from Abraham to David and Christ, hence the Matthew version (Mt 1:1-17) as opposed to the genealogy of Luke (Lk 3:23-38). The genealogical lineage of Matthew is drafted in the first lines of his gospel:

The Book of the generation of Jesus Christ,

the son of David, the son of Abraham (Mt 1:1).

Although absent among the preserved parts of the nave mosaics, a Davidic episode may have concluded the Exodus/Joshua cycle on the south wall (infra). Since the theologians who planned the iconographical system included in the christological cycle the Adoration of the Magi (Mt 2:1-12), the Flight into Egypt (Mt 2:13-15) and the Massacre of the Innocents (Mt 2:16-18), stories that are narrated solely by Matthew, it would seem that the two first chapters of this Gospel could serve as a key to the interpretation of the entire iconographical system. Another feature that supports such a hypothesis is the angel who, in the upper zone, left side, turns towards Joseph with his hand raised in a speaking gesture. He is commonly interpreted as the angel who, in Mt 1:20, brings the announcement to "Joseph, son of David", telling him that the Child had been conceived by the Holy Spirit. In a preparatory drawing found on the wall beneath 


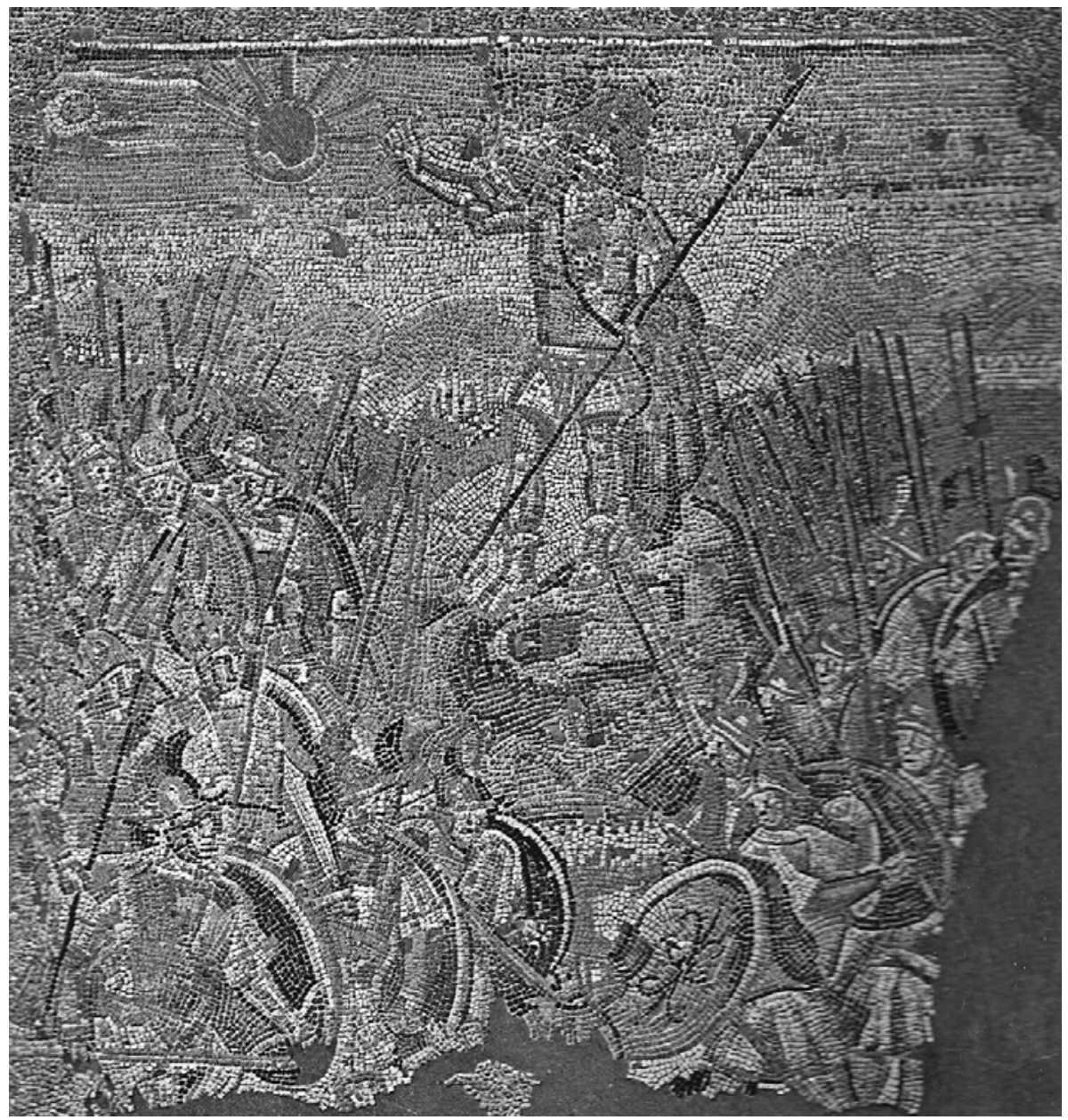

FIg. 8 - Santa Maria Maggiore, Joshua cycle of the nave: Panel 18 (right wall), The Sun and the Moon standing still over Gibeon (after J. Wilpert - W. Schumacher 1976).

the mosaic this episode was rendered with even greater accentuation: the angel is here depicted as flying, and mirrors the angel in the Annunciation scene. ${ }^{47}$

Since the story of the Presentation in the Temple is solely narrated in the Gospel of Luke (Lk 2:22-40), and since the spinning motif incorporated in the Annunciation scene (infra) comes from the Protoevangelium of James, the presumed influence from Matthew should be limited to some general principles underlying the iconographical system. As stated above, it seems that the Old and New Testament scenes of S. Maria Maggiore may, as in the first chapter of the Gospel of Matthew, particularly stress:

47. Grabar 1936, 227; Weis 1960, 79: Abb. 5. 
1. the genealogy of the human nature of Christ from Abraham through David, and

2. the divine descent through the Holy Spirit, fulfilling the prophecy of Is 7:14 cited in Mt 1:22-23, and also the prophecy of Hosea 11:1 referred to in Mt 2:15, where it is stated that Joseph departed into Egypt "that it might be fulfilled which was spoken of the Lord by the prophet: Out of Egypt have I called my son", thus proclaiming that Jesus is the Son of God.

It is significant that Egypt plays a central role both in the Old Testament cycles of the nave and in the New Testament cycle on the arch. We should carefully listen to the exegesis of Leo the Great in one of his sermons on Epiphany, where Egypt, thematically, is being linked to the idea of the Passover, i.e. the Salvation:

While the dignity of the chosen race is proved to be degenerate by unbelief in its descendants, it is made common to all alike by our belief. The massacre of the Innocents through the consequent flight of Christ, brings the truth into Egypt. [...] He who was postponing the shedding of His blood for the world's redemption till another time, was carried and brought into Egypt by his parents' aid, and thus sought the ancient cradle of the Hebrew race, and in the power of a greater providence dispensing the princely office of the true Joseph, in that He, the Bread of Life and the Food of reason that came down from heaven, removed that worse than all famines under which the Egyptians' minds were labouring, the lack of truth, [...] for there [in Egypt] first by the slaying of the lamb was fore-shadowed the health-bringing sign of the Cross and the Lord's Passover. ${ }^{48}$

The historical circumstances behind the generation (geneseos) of [the human] Jesus Christ, the "Son of Abraham, son of David" (Mt 1:1), and the actual divine descent that led to the birth (genesis) of Christ (Mt 1:18), were equally important for the christological thinking of the fifth century in the interlude between the Councils of Ephesus and Chalcedon, and not least on Roman soil. As we have stressed, this two-nature Christology is found in Pope Leo the Great's teachings, as in his Tomus ad Flavianum and in his Sermons on the Nativity of Christ: Leo underlines that the Virgin was the mediator of the royal seed of David, becoming the flesh of the Logos, a rhetoric that was of utmost importance in the contemporary struggles against the heresy of Monophysitism. The Leonine bias of the iconography of the triumphal arch, stressing the christological and soteriological meaning of the Davidic Messiah, was, as we have seen, a crucial point in the interpretation already presented by Sieger; according to R. Krautheimer, Leo may "as early as the time of Sixtus, [...] have drawn up the program for the mosaic cycles in the nave and on the triumphal arch of S. Maria Maggiore" ${ }^{49}$ Moreover it might be suggested that the thoughts in the minds of the theologians of early

48. Leo the Great, Sermo 33 (3), 3-4, Sources Chrétiennes 22bis, 207-208.

49. Krautheimer 1980, 51. 


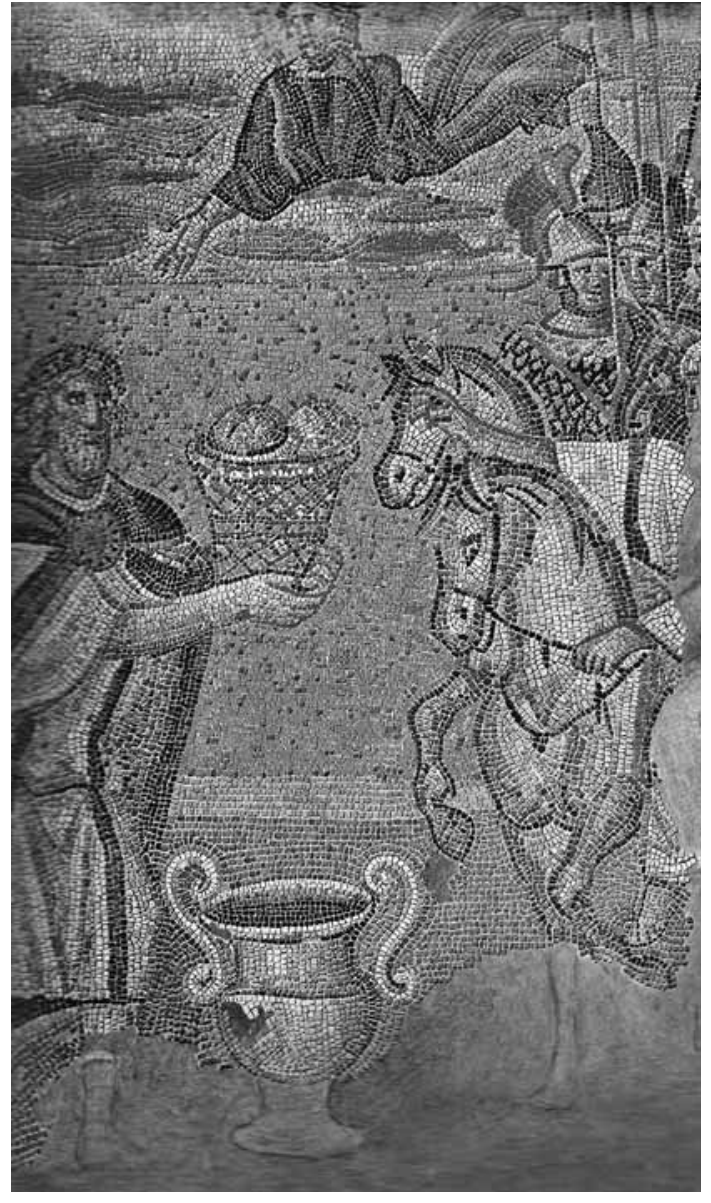

Fig. 9 - Santa Maria Maggiore, Genesis cycle of the nave: Panel 1 (left wall), Melchizedek and Abraham (after J. Wilpert - W. Schumacher 1976).

fifth-century Rome were influenced by the same ideological circle that had given rise to the spirituality of the Saint himself.

In the exegesis on Matthew from which we have quoted above, Nolan (1979) links the divine providence brought about by the inclusion of the four women in the genealogy of Christ, with the divine providence manifested through the conception of the Logos: "Of the many explanations offered, the most acceptable is also one of the most traditional: all five women [Tamar, Rahab, Ruth, Bathsheba, the Virgin Mary] show divine providence at work in an extraordinary way. Matthew 1 welcomes this evidence that the Lord God has his own logic, which all too few of his people have been able to follow. Neither human malice nor racial prejudice excluded Tamar, Rahab, Ruth, or Bathsheba from the blessings promised to Abraham. Like Mary, each had a (not necessarily sinful) irregularity and a marriage difficulty [Tamar and Bathsheba]. All this provides an apt setting for the genesis of the Christ through the intervention of the Spirit. The five heroines show forth the divine fidelity, his sovereign power and overriding purpose at work and so do both the opening chapters of Matthew." 50

Representations of Rachel and Leah appear in several of the panels in the Genesis cycle in the nave; it was Judah, the fourth of the sons that Jacob fathered from Leah (Gen 29:35), who, through the divine selection [of Tamar], became the mediator of the seed of Abraham in the genealogy of David and Christ: the seed of Abraham was thus multiplied through the exceptions, i.e. the sterile women (Sarah, Rebecca and Rachel) who became fertile, the role

50. Nolan 1979, 119. 
played by Tamar (Gen 38), and the Gentile women (Rahab and Ruth) ${ }^{51}$ who were 'mothers' (respectively great-great grandmother and great-grandmother) in the genealogy of King David.

A comparative iconographical programme, which dates to the fifth century and commemorates the human ancestry of Christ through Judah, is found in a fragmentary cycle of Old Testament Patriarchs in the atrium of the St. Aquilinus Chapel of S. Lorenzo Maggiore in Milan. In the panel representing Judah, the son of Leah, we find a small scene to the upper left describing the meeting between Judah and Tamar (Fig. 7) and including their twins Pharez and Zerah (Gen 38). The present author will suggest that one of the four lost panels that concluded the Genesis cycle in S. Maria Maggiore may have had a scene corresponding to the one in the Aquilinus Chapel in Milan. ${ }^{52}$

A reading of the iconographical system on the basis of the genealogy given in the Gospel of Matthew, including the assumption that the matron in the Adoration scene may refer to the Gentile women in the genealogy of Christ, would seem to remind us that in the seed of Abraham, which means in Christ (Gal 3:16), two people were joined: the Israelites in blood and faith and the Gentiles. The meaning of the motif may therefore be comprehended in ecclesiological as well as in christological terms.

51. Nolan stresses the exegetical levels of meaning behind the listing in Mt 1: 1-17 of the four Gentile woman: "Tamar, Rahab and Bathsheba were sinners [...]. The scriptures are explicit about the paganhood of Rahab the Canaanitess and Ruth the Moabitess. [...]. Philo considers [Tamar] to be of Gentile stock [...]. Since exogamy was outlawed in the first century, Bathsheba, the wife of Urias the Hittite, would automatically be adjudged to be non-Israelite. [...] Pagans all four may be, but the Gentile uncleanness of Rahab and Ruth, and even of Tamar, falls away as they later emerge as proselytes.” Nolan 1979, 63.

52. It is significant, from a methodological point of view, to be aware that our interpretation of this particular motif, as well as of the complete pictorial cycle of Old Testament scenes, depends on whether we, with Brenk, rely on typological exegesis, maintaining that every scene may be interpreted in figurative terms, for instance of the Synagogue versus the Ecclesia, or whether the scenes should primarily be seen as a continuous narrative, as in the present article, where the meaning is implicit in the description of the genealogy of Christ, independent of the Ecclesia concept. According to Brenk, the mosaic in the Aquilinus Chapel, describing Judah and Tamar with the twins Zerah and Pharez between them, is, in Ambrosian terms, primarily conceived in ecclesiological terms [Brenk, 1975, 110]:

\begin{abstract}
"Mit der zweifachen Lebensweise der Völker hat Ambrosius die Gleichung Zara=Ecclesia, Phares=Synagoge im Auge. Auf dem Mailänder Mosaik kauern die beiden Zwillinge Zara und Phares am Boden, links und rechts von der Mutter Thamar. Sie zind keineswegs identisch dargestellt, sondern der eine trägt ein Gewand von leuchtend Rotoranger, der andere eines von türkisblauer Farbe, m.a.W. die farbige Differenzierung entspricht genau den Gestalten der Rachel und Lea in SMM. Wir haben Grund zu Annahme, dass das theologische Gedankengut des Mailänders Ambrosius in SMM in Rom eine Rolle gespielt haben dürfte." The implication of St. Ambrose's exegesis is that Zerah becomes the main person, as he prefigures the Ecclesia. If, however, the genealogy of David and Christ's human nature in anti-Monophysitic terms were the main subject in the mind of the theologians who planned the programme, then the focal point would shift to the role of Pharez, who would become an ancestor of the stock of Jesse and David. From the point of view of the present author we should not exclude the possibility that both ways of interpreting the cycles may not be incompatible: both may have been valid at the time when this programme was laid out. This flexibility will open new paths for our conception of the iconographical meaning of the present system.
\end{abstract}




\section{The human nature of Christ as prefigured by King David}

We shall now return to the David-Christ typology suggested above, as well as to the meaning expressed through the strict symmetrical organization of the two women who flank the throne of Christ in the Adoration scene. The thesis that the general lay-out of the programme is based on the first two chapters of Matthew's Gospel, and that the woman clad in the blue maphorion is inserted as a witness to and a link in the genealogy of Christ, may help to reveal some of the ideological structures in our material: as we have suggested, it can throw light on the theological discourses taking place in Rome in the wake of the Ephesian Council.

The Roman Episcopate was deeply concerned with the teachings of Cyril of Alexandria's extremist allies, who maintained that the human nature of Christ was consumed by the Logos. These followers strove to re-assert the Cyrillic "one-nature

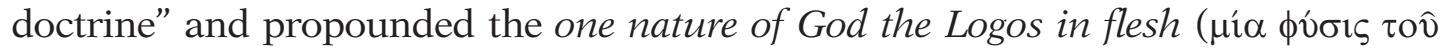

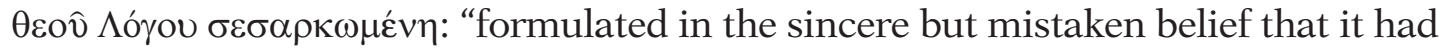
the authority of the great Athanasius behind it, but deriving instead from certain treatises of Apollinarian provenance" ${ }^{53}$ ), in spite of the fact that Cyril himself had accepted the far more moderate two-nature formula (a formula maintaining that the Incarnation brought about "a union [ $\varepsilon v \omega \sigma i \varsigma]$ of two natures") contained in the document called Symbol of Union. ${ }^{54}$ This document was a crystallisation of the Ephesian doctrine ${ }^{55}$; its balanced form, although not formulated by the Alexandrine bishop, may be designated as a reflection of the moderation of Cyril himself (as opposed to his follower Dioscorus), and an anticipation of the Christology of Leo the Great as expounded in some of his sermons, as well as in his famous letter to Flavian, the bishop of Costantinople. This Tomus ad Flavianum, condemning the heretical teachings of Euthyches (AD 449), became the textual backbone in the Decrees of the Council of Chalcedon in AD 451; hence it may postdate our cycles by 15-20 years. Still, the ideological matrix of the text may reflect ideas characteristic of the Roman tradition, including those held at the time of the pontificate of Sixtus III. Leo expounds in his Tomus ad Flavianum that:

[Euthyches] should have subjected himself to the teachings of the gospels. When Matthew says, The book of the generation of Jesus Christ, son of David, son of Abraham [Mt 1:1-16], Euthyches should have [...] paid deep and devout attention to the prophetic texts $[\ldots]$ Then he would not deceive people by saying that the Word was made flesh in the sense that he emerged from the Virgin's womb having a human form but not having the reality of his mother's body. [...] The activity of each form is what is proper to it in communion with the other: that is, the Word performs what belongs to the Word, and the flesh accomplishes what belongs to the flesh. [One of these performs brilliant miracles; the other sustains acts of violence. [...] We must say this again and again: ] one and the same is truly Son of God and truly son of man. ${ }^{56}$

53. Kelly 1977, 319.

54. Kelly 1977, 328-329.
55. Tanner 1990, 69-70.

56. Tanner 1990, 77-79. 
As becomes clear from these excerpts from his Tomus ad Flavianum, Leo argues for the two-nature doctrine by reference to the lineage of David (the human ancestry of Christ listed in Mt 1:1-16). The repeated statements in his writings about the genealogy of Christ, running through the house and lineage of David (in accordance with I Chronicles 17:11; Mt 1:1-16; Lk 1:32; 3:23-38; Rom 1:3), were part of the Saint's verbal struggle against Monophysitism, whose adherents underrated, or repudiated, the significance of the human nature of Christ for the salvation of man.

It is against the backdrop of such considerations that the two women on the arch may appear in a new light. A fresh study of the iconography of the decoration in S. Maria Maggiore in its totality has led me, moreover, to the postulate that the series of stories from Exodus and Joshua may have been concluded with a scene drawn from the life of David - his birth, his triumph over Goliath, his anointment, or some other central episode.

Finally, in the Childhood cycle on the triumphal arch, the story of David seems to be reiterated through a visualization of the Child sitting on the large throne, which may allude to the kingship of his great ancestor. Here the Magi, in the words of Leo, "may at the same time show their belief in His threefold function: with gold they honour the person of a King, with myrrh that of Man, with incense that of God". ${ }^{57}$ The royal appearance of the Child here has a double meaning: (1) He is the Heavenly King, a role that is even visualized through his white vestments - the white linen being a symbol of the divine, as in the cloths covering the newly baptized, the alba of the priest etc. (2) Yet the motif of the enthroned Child also reminds us of his Kingship on earth, inherited through the lineage of David. It would therefore seem that the compositional relationship between Christ and the two women who flank him reflects his two natures: the Virgin, his mother, through the fulfilment of the history of salvation, is the bearer of the Logos in flesh (Jn 1:14), while the matron, whether she be interpreted as Ruth, Rahab, or as a general personification of the Old Testament genealogy of Christ, extols the human ancestry of Christ from Abraham through David, as well as the divine providence, the inscrutable ways that God works out his divine plan according to His wisdom.

The presence of David in the concluding panels might even be conjectured on the basis of another key motif in the cycle of Old Testament scenes: the Melchizedek panel, which opens the narrative sequence of the Genesis scenes. King David, the Psalmist, says:

The Lord hath sworn, and will not repent;

Thou art a priest forever after the order of Mel-chiz-ed-ek. [Ps 109 (110): 4]

57. Leo, Sermo 33 (3), 1: Sources Chrétiennes 22bis, 203 . 
It might therefore seem that a cycle opening with Melchizedek and closing with David would add further depth to the christological meanings concealed in the pictorial system of the Old Testament scenes.

\section{The Melchizedek panel}

The location of the Melchizedech panel ahead of the Genesis cycle, hence in juxtaposition to the altar, would seem to stress that the scene has liturgical overtones: the prayers as well as the general conception of the Canon of the Mass. ${ }^{58}$ This does not exclude, however, that the introduction of the Melchizedek panel (Fig. 9) at the head of the Old Testament cycle - in spite of the fact that in the text of the Bible, the Separation of Abraham and Lot (Gen 13:11f.) precedes the narrative about Melchizedek, priest of Salem (Gen 14:17) - may be expressly christological, and that it was put there in defence of the two-nature doctrine. Moreover, it might be suggested that the christological meaning of this figure is not restricted solely to the exegesis in the Epistle to the Hebrews, which says:

[Melchizedek is] without father, without mother, without descent, having neither beginning of days, nor end of life; but made like unto the Son of God, abideth a priest continually [Heb 7:3]

The statement that Melchizedek had no father and mother led the Fathers of the Church to an exegesis in christological terms, maintaining that Christ, his antitype, was without father as a human and without mother as a divine: hence, that he was both divine and human. In the cycle in S. Maria Maggiore, Melchizedek is represented in the act of bringing bread and wine as he blesses Abraham (emerging to the right together with his fellow soldiers), who returns from the defeat of Chedorlaomer. God, who appears in the sky, has his right hand outstretched in the act of receiving the bread from the offering priest of Salem.

And Melchizedek king of Salem brought forth bread and wine: and he was the priest of the most high God. And he blessed him and said: blessed be Abraham of the most high God, possessor of heaven and earth [Gen 14:19].

58. In the Supra quae prayer we beseech God to look with favour on the gifts on our altar on earth as he once looked with favour on the sacrifices of Abel, Abraham and Melchisedek. According to J.A. Jungmann, "at least the core of the Roman canon must have existed by the end of the fourth century. In an anonymous text of this period a phrase is cited from the Supra quce [...]" (Jungmann I, 1992, 51). This means that the relatively large figure of Melchizedech in the mosaic panel of S. Maria Maggiore was probably conceived as a liturgical image of the presentation of bread and wine, corresponding to the Supra qua of the Roman Canon. The repast taking place in the scene of the Hospitality of Abraham that follows the Melchisedech panel is in no way contrary to such an interpretation. For a corresponding interpretation of the Old Testament panels in the sanctuary of San Vitale in Ravenna see: C.-O. Nordstöm 1954, 104-106. 
The Fathers of the Church searched deep into the christological meaning of the Melchizedek figure. Thus St. Gregory of Nazianzus says in his Oration on Theophany:

Who will not worship the one who is from the beginning? Who will not glorify the one who is the last? Again the darkness is past; again Light is made; again Egypt is punished with darkness; again Israel is enlightened by a pillar. Let the people who sat in darkness of ignorance see the Great Light of full knowledge. Old things are passed away, and all things are become new, the letter gives way, the Spirit comes to the front. The shadows flee away; the truth comes in upon them. Melchizedek is concluded. He that was without mother becomes without father (without mother of his former state, without father of his second). The laws of nature are upset; the world above must be filled. Christ commands, let us not set ourselves against him. ${ }^{59}$

It is remarkable that Proclus, Patriarch of Constantinople from AD 434 to 446 (hence a contemporary of Sixtus III), relies on the same typological conception of the figure of Melchizedek in his Oration on the Mother of God (Oratio de laudibus S. Mariae):

\section{Oratio 1}

IV. [About Christ in the likeness of Melchizedek:] He who is by nature impassable has become passable on account of his mercy. Not from moral progress has Christ become God; assuredly not! But on account of his mercy God in whom we believe has become man. We do not preach a man who was deified, but we confess God who was incarnate. It is recorded that he who in his essence is without a mother and in his Economy without a father has made the [form of a] servant his own. How is the same one without a mother and without father according to Paul? If he were a mere man he would not be without a mother for he has a mother. If he were only God he would not be without a father for he has a Father. But now the same one is without mother as the Creator, and without father as the created. ${ }^{60}$

The pre-figuration of Christ as the priest of Salem holds a central position in Proclus' argument in defence of his anti-Nestorian Christology and Mariology. ${ }^{61}$ Proclus points out that while the Divine Logos is without mother, the Logos incarnate was born by a carnal mother (although He had no carnal father), which implies that the Virgin is a God-bearer (Theotokos). The Logos incarnate was rex et sacerdos secundum ordinem Melchisedech, which means that as a priest Christ reconciles everything with the Father while as a king he cares for $\mathrm{Man}^{62}$, an expression that underlines the soteriologically crucial implications of the divine and human nature of Christ. Being the King of Salem (=Jerusalem, cf. Ps 75[76]:3), Melchizedek is also

59. Oratio 38.2. Translation in: Wesche 1991, 129130.

60. Migne 1864, PG 65 683C-686 A. The English translation: Wesche 1991, 130.
61. Melchizedek is already present in Oratio 1, and reappears in Oratio 4.

62. Migne 1864, PG 65 723-724 CD. 
a pre-figuration of King David; this can be counted as further evidence in favour of the above hypothesis that a Davidic scene concluded the Old Testament cycle.

\section{The purple thread}

We will now return to the Annunciation scene (Fig. 3) on the triumphal arch. Why is the Virgin spinning purple thread and not the white linen of the priestly alba? As pointed out by earlier scholarship, the Virgin in the Annunciation scene in S. Maria Maggiore is spinning purple thread for the curtain of the temple, an episode that has its textual basis in the Protoevangelium of James. Actually, the Apocrypha explicitly asserts that she was selected for this honourable task since she was of the royal house and lineage of David. In the Gospel of Luke (Lk 1: 32), too, the Angel Gabriel tells the Virgin that her Son "will inherit the throne of David". The spinning of the purple thread for the curtain of the temple therefore must refer to the kingship of Christ: for purple is the colour of royalty. Purple here directly alludes to the human kingship of Christ through the lineage of David and Solomon, prefigured in Melchizedek. The deeper meaning behind the purple thread of the Annunciation scene in S. Maria Maggiore was analysed by Sieger, who maintains that: [...] "scarlet is not only [...] the colour of royalty, but $[\ldots]$ the only sign of salvation. The scarlet thread [...] symbolizes the reality of the salvific blood of Christ, the reality of his Passion, which Leo attributes to Christ's human nature. For Leo, an essential aspect of the Annunciation's theological significance is that the Virgin is responsible for the reality of Christ's human nature. This is expressed in the Annunciation mosaic by showing Mary spinning the scarlet thread for weaving the 'veil' of Christ's humanity". ${ }^{63}$

Sieger stresses the link between the spinning of the scarlet thread in the Annunciation scene and the scarlet thread that saved the house of the harlot Rahab in Jericho (Joshua 2:18). To the brilliant analysis of Sieger just quoted it is tempting to add that of Proclus who, in his Oration on the Honour of the Virgin, develops the metaphor of weaving and textiles in his description of the Annunciation:

Holy Mary [...] awe-inspiring loom for God's saving plan, on which the garment of unity was indescribably woven, whose weaver is the Holy Spirit, and whose spinner is the overshadowing power from on high, whose wool is the old sheepskin of Adam; the warp is the immaculate flesh of the Virgin, the shuttle the measureless grace of her who bore him [...]. [Oratio I $]^{64}$

63. Sieger $1987,86$.

64. "Maria $[\ldots]$ animatus naturæ rubus, quem divini partus ignis non combussit [...] que sedentem super Cherubim, corporatum portavit; mundissimum vellus imbris cælestis, ex quo pastor ovem induit. Maria, inquam ancilla et mater, virgo, ac cælum, Dei ad hominess unicus pons, horrendem incarnationis textorium jugum, in quo innefabili quadam ratione unionis illius tunica confecta est. cujus quidem textor extitit Spiritus sanctis; nectrix, virtus obumbrans ex alto; lana antiquum Adami vellus; trama impolluto cara ex virgine; textorius radius, immense gestantis gratia [...] (Migne 1864, 681-682 B). The English translation: Daley 1988, 2-3. 
The Virgin is here described as a loom in God's hands, on which is woven a new mantle from the wool that covered the Old Adam; the flesh of the Virgin (the thread that is being woven) becomes the Temple of the Logos. ${ }^{65}$ There is also a Biblical passage that may be cited in support of the deeper meaning found behind the act of spinning the thread for the curtain of the temple as narrated in the Protoevangelium. In the Epistle to the Hebrews it is expounded that 'our hope reaches through the Curtain of the Temple'66, hence

[...] there is no more offering for sin. Having therefore, brethren, boldness to enter into the holiest by the blood of Jesus, by a new and living way, which he hath consecrated for us, through the veil, that is to say, his flesh (Heb 10:18-20).

Here, the author of the Epistle uses metaphorical terms to explain that the curtain of the temple, through which Jesus has passed, is a figure of the Saviour's flesh. The metaphor of the veil adopted here is indeed close to the one used by Proclus, in spite of the latter's flowery poetic style.

\section{Concluding remarks}

To sum up our argument, we will return to some main points in our analysis of the iconographical system in its totality. All of the New Testament scenes on the triumphal arch describe events from the Childhood of Christ, yet none of the single motifs of the Old Testament cycles in the nave correspond to the scenes of the New Testament in the typological one to one relationship ${ }^{67}$ we know from similar cycles of the Old and New Testaments in some of the basilica-churches, such as Old St. Peter's and San Paolo fuori le mura) ${ }^{68}$ Evidently, no attempt to establish a concordantia of this type was made here. In composing the Old Testament cycles an overriding aim, however, was the singling out of events and persons particularly significant for the elucidation of the multiplication of the seed of Abraham, and among these scenes the great-great grandmother of David, the harlot Rahab, is relatively prominent. The iconographical system of the basilica thus seems to express that the history of salvation, as narrated through this Old Testament programme, culminates in the representations on the triumphal arch in which the Virgin is the protagonist: she is the bearer of the Word made flesh, which is both God and Man.

65. Migne 1864, 683-684 B.

66. Hebr 6, 19.

67. This, however, does not exclude that the third panel in the Moses cycle, describing the theophany in the Burning Bush, has Marian overtones (cf. St. Gregory of Nyssa, De vita Moysis, Part II. 21). Since, however, the scene is not located at the head of the cycle (as is the
Melchizedek panel on the corresponding wall) and since it is small, and thereby difficult to decipher from the floor level of the church, it would seem that the narration of the story is here more significant than the deeper meaning that can be extracted from theological exegesis.

68. cf. Grabar 1968/1980, 140. 
The fact that the Virgin in the Childhood scenes is dressed like an empress, is, as we have seen, a piece in the iconographic puzzle on the triumphal arch that has attracted the attention of several generations of researchers. Adopting a viewpoint that stresses the christological meaning of the Old Testament scenes alluding to the genealogy of Christ, Sieger argues that the Virgin wears the golden vestments since she was of the royal house of David (as affirmed in the Protoevangelium of James [see supra]). Her thesis seems a plausible explanation for the deviation, in this iconographical setting, from the traditional maphorion type. ${ }^{69}$ That Mary was of the royal lineage of David was also of the utmost importance in Leo the Great's rhetoric against Monophysitism. Leo's christological teachings in his sermons and in his Tomus ad Flavianum prepared the ground for the Council of Chalcedon. ${ }^{70}$ The view of the present author is that in Leo's teachings we perceive the ideological matrix for the programme of the mosaics of S. Maria Maggiore, in both its Old Testament and New Testament cycles. ${ }^{71}$ Our analysis has even led us to the conclusion that the genealogy, geneseos, of Christ in Matthew 1:1 is a determining principle behind the organisation of the Old Testament cycles, since the Annunciation scene, as well as the iconographical setting of the triumphal arch in general, would seem to extol the divine descent through the Birth of Christ, the genesis, as narrated in Matthew 1:18.

As is also strongly underlined by Sieger, ${ }^{72}$ the Land of Egypt has a central position in the pictorial system here studied. We may assume that the Genesis cycle was probably concluded by a representation of Joseph and his brothers in Egypt, followed by the Exodus from Egypt, as it survives in the cycle on the south wall of the nave. Furthermore, this cycle, describing the Passover, has the harlot Rahab located in a key position. Her house represents the Church, she herself the salvation, particularly the salvation of the Gentiles. ${ }^{73}$ The soteriological

69. Sieger 1987, 85-86. As is well known, the Virgin is dressed in royal vestments in the Milan diptych [Volbach 1958, Abb. 100; Brenk 1975, Abb. $15.1 \& 15.2]$, which, as far as the present author knows, is the only surviving fifth-century parallel to the dress of the Virgin on the arch of $\mathrm{S}$. Maria Maggiore. In this diptych the Virgin wears the royal trabea in the Presentation in the Temple and the Annunciation. These motifs derive from the apocryphal Protoevangelium of James, where it is affirmed that Mary was selected to spin the threads of purple and scarlet for the veil of the Temple since she was of the house and lineage of King David. In Chapter 12 of the Protoevangelium it is stated that Mary went to the river to fetch some water when she suddenly heard a voice greeting her. In the diptych the Virgin is represented on the banks of the river, in the act of collecting water in an amphora; she turns toward an Angel, whose speaking gesture signifies that he greets her with the divine blessing. Since the scenes describing the Virgin in the Milan diptych derive from the Protoevangelium, it might be asked whether the trabea also here alludes to the Virgin's royal ancestry.

70. The "Definition of the Faith" was promulgated at the sixth session of the Council. The formula accepted in the decree: Christ is one in two natures is in agreement with Leo the Great's Tomus ad Flavianum, which is expressly mentioned in the Definition of the Faith. See: Tanner 1990, 75-87, which contains an English translation of Leo's Tomus.

71. According to Krautheimer [Krautheimer 1980, 51], Leo may have ordered the walls of Rome's great basilicas to be decorated with biblical cycles.

72. Sieger $1987,86-88$.

73. Cf. n. 45. 
meaning of the Exodus is therefore condensed in the three Jericho scenes; here Rahab is represented in all three panels, and the scarlet thread, the Symbol of salvation (cf. The Annunciation Scene), is shown in one of them.

This is why I find it reasonable to assume that the woman in a maphorion in the Adoration of the Magi scene may be a personification of the Gentiles in the genealogy of Christ, acting as a prophetess of salvation. ${ }^{74}$ Such an interpretation derives further support, it seems to me, from the presence in the same tier on the right side of the arch of the Reception of the Holy Family in Egypt, obviously alluding to the 'Second Exodus', when God, once again, called his Son out of Egypt (Matt 2: 15/Hosea 11:1). ${ }^{75}$

The conception of Egypt has thus turned from being the symbol of evil to the symbol of faith, a meaning that seems strongly to be reiterated in the scene describing the Presentation in the Temple. Here Grabar (1936) noticed that on the tympanon of the temple there is a representation of a sculpture that can be identified as none other than the Dea Roma of the Templum Urbis, the Temple of Venus and Rome. According to Grabar, the scene should not solely be considered as the Presentation of Jesus in the Temple of Jerusalem; he suggested that the scene shows the [pagan] Old Rome, the Roma aeterna now receiving the Christ, hence, the Roma aeterna becoming the Christian Seculum novum, the seat of the Christian reign for the thousand years (Rev 20:4 ff.). Moreover, Warland (2003) draws our attention to the Gorgon heads on the temple front, maintaining that these, in all probability, describe the frieze of heads located above the entablature in the Templum Urbis. ${ }^{76}$ On this basis Warland postulates that the woman in the blue maphorion in the Adoration scene is the Roman Sibyl. ${ }^{77}$

Warland's rather perceptive elaboration of Grabar's observations fails, however, to answer the question why the two women are counterbalanced on each side of Christ. In a symmetrical composition, like that of the two women flanking Christ in the Adoration scene, it seems reasonable to assume that the matron was inserted in the scene to express a meaning that was related to the

74. Can it be excluded that this possibly even alludes to the Egypt/Rahab theme in the Exodus/ Joshua cycle? There is, in fact, an interesting exegesis even on the name Rahab, as the following Augustinian interpretation of Psalm 86, (87): 4 will show: St. Augustine states that the name Rahab in this Psalm does not only signify Egypt; he moves from the Rahab/Egypt identification of the Psalm to a broader association between Rahab/Egypt and the harlot Rahab of Jericho: "Listen whence: 'I will think upon Rahab and Babylon, with them that know Me' (verse 4). In that city, the Prophet, in the person of God, says, 'I will think upon Rahab and Babylon.' Rahab belongs not to the Jewish people; Babylon belongs not to the Jewish people; [...]
'I will think,' he says, 'upon Rahab: 'who is that harlot? That harlot in Jericho, who received the spies and conducted them out of the city by a different road: who trusted beforehand in the promise, who feared God, who was told to hang out of the window a line of scarlet thread, that is, to bear upon her forehead the sign of the blood of Christ. She was saved there, and thus represented the Church of the Gentiles'."

75. Sieger 1987, 87.

76. Warland 2003, 130; 134-138.

77. Recently G. Steigerwald has objected to Warland's interpretation, holding that the temple in the Presentation scene can be nothing else than the Temple of Jerusalem: Steigerwald 2003, 77-81. 
Virgin on the opposite side: a meaning that is kept strictly within the same logical categories as in the representation of the Virgin herself. That is why the present author suggests that the woman in the blue maphorion may be a personification of the Gentiles in the genealogy of Christ: the aspect of Gentile motherhood in the genealogy of Christ (particularly the contribution of Rahab and Ruth) may explain her position flanking the throne of the Davidic Messiah.

These speculations on the identity of the woman in the blue maphorion should not, however, blur the fact that Grabar's interpretation of the Presentation scene, his stressing of its double meaning, and his argument that the scene has a pro-Roman bias, with strong Church political overtones, also helps to explain the position of Egypt in these pictorial cycles: the 'Old' Egypt is contrasted with the 'New' (i.e. Rome) ${ }^{78}$. Egypt, as well as Rahab, represents the Gentiles, as do the priests of the Templum Urbis, and, seemingly, the woman in the blue maphorion.

It was the Roman Episcopate that led the battle in the christological controversies in the interlude between the Councils of Ephesus and Chalcedon. The emphasis placed, in the S. Maria Maggiore cycles, on the genealogy of David and Christ through the Old Testament cycles, and hence on the human nature of the Saviour, seems to be an iconographic correlate to the theological teachings of the Roman Church directed against the danger of Monophysitism, as posed by the zealous allies of Cyril of Alexandria. From the same point of view, and contrary to the thesis of Saxer (above p. 2), the Virgin Mary appears to be the very matrix of the system, she who gave birth to the Word that was made flesh a flesh that derives from the seed of Abraham through David.

Per Olav Folgerø

Nystuveien 29

N-5019 Bergen, Norway

78. Cf. Sieger supra n. 46. 


\section{BIBLIOGRAPHY}

Ahlquist A. 1991: "Ett bidrag till ecclesiaikonografin i senantikk tid: S. Maria Maggiore i Rom", in Teologinen Aikakauskirja/Teologisk Tidsskrift nr. 2, 109-132.

Berchem M. v. - Clouzot E. 1924: Mosaiques chrétiennes du IVme au Xme siècle, Geneva.

Brenk B. 1975: Die früchristlichen Mosaiken in S. Maria Maggiore zu Rom, Wiesbaden.

Calcagnini D. 2002: "Le figure femminili nel mosaici paleocristiani degli edifici di culto romani", in

Ecclesia Urbis, Atti del congresso internazionale di studi sulle chiese di Roma (IV-X secolo), Città del Vaticano 2002, 1919-1938

Cecchelli C., Furlani G., Salmi M. (eds.) 1959: The Rabbula Gospels. Facsimile Edition of the Miniatures of the Syriac Manuscript Plut. 1, 56 in the MedicaeanLaurentian Library.

Daley B.E. 1988: On the Dormition of Mary. Early Patristic Homilies, St Vladimir's Seminary Press, Crestwood New York.

Daniélou N. 1960, From Shadows to Reality. Studies in the Biblical Typology of the Fathers, London.

Deckers J.G. 1982: "Die Huldigung der Magier in der Kunst der Spätantike“, in Die Heiligen drei Könige. Darstellung und Verehrung (exhibition catalogue), Cologne.

Garrucci P.R. 1873-1881: Storia dell' arte cristiana nei primi otto secoli della chiesa IV. Prato.

Grabar A. 1936: L'Empereur dans l'art byzantin, Paris.

Grabar A. 1968: Christian Iconography. A Study of Its Origins. New Jersey.

Guckin, J. Mc. 2004, Saint Cyril of Alexandria and the Christological Controversy. Its History, Theology, and Texts, St. Vladimir's Seminary Press, Crestwood, New York.

Jastrzebowska E. 1992: Bild und Wort: Das Marienleben und die Kindheit Jesu in der christlichen Kunst vom 4. 8. Jh. und ihre apokryphen Quellen, Warsaw.

Jungmann J.A. 1992: The Mass of the Roman Rite. Its Origins and Development, Westminster, Maryland.

Kelly J.N.D. 1977: Early Christian Doctrines, London.

Kemp W. 1994: Christliche Kunst. Ihre Anfänge. Ihre Strukturen, München 1994.

Kondakov N.P. 1886: Histoire de l'art byzantin, I, Paris.

Krautheimer R. 1980: Rome. A Profile of a City, 3121308, New Jersey.

Künzle P. 1961/62: "Per una visione organica dei mosaici antichi di S. Maria Maggiore”, in Atti della pontificia academia romana di archeologia. Rendiconti 34, 153-190.

Leclercq J. \& Dolle R. 1947: Sources Chrétiennes 22bis, Paris.

Marini Clarelli M.V. 1996: "La controversia nestoriana e i mosaici dell'arco trionfale di S. Maria Maggiore", in C. Barsanti (ed.), Bizanzio e l'Occidente. Studi in onore di Fernanda de`Maffei, Rome, 323-344.
Migne J.-P., 1864: Patrologice Grcecce Tomus 65 (PG 65), Paris.

Nolan B.N. 1979: The Royal Son of God. The Christology of Matthew 1-2 in the Setting of the Gospel, Göttingen.

Nordhagen P.J. 1983: "The Archaeology of Wall Mosaics: A Note on the Mosaics in S. Maria Maggiore in Rome”, in The Art Bulletin, 65 (2), 323-324.

Nordström, C.-O. 1953: "Ravennastudien. Ideengeschichte und ikonographische Untersuchungen üer die

Mosaiken von Ravenna”, Figura 4, Uppsala.

Pietri Ch. 1976: Roma Christiana, Rome.

Richter J. P. \& Cameron Taylor A. 1904: The Golden Age of Classic Christian Art, London.

de Rossi G.B. 1899, Musaici delle chiese di Roma e saggi dei pavimenti anteriori al secolo $X V$, Rome.

Saxer V. 2001 : Sainte-Marie-Majeure. Un basilique de Rome dans l'histoire de la ville et de son église $V-X I I I$ siècle), Rome.

Schubert U. 1995 : "Die Kindesgeschichte Jesu als politische Theologie am Triumphbogenmosaik von Santa Maria Maggiore in Rom" in Byzantine East, Latin West. Art Historical Studies in Honor of Kurt Weitzmann, Princeton New Jersey, 81-89.

Sieger J. D. 1987: "Visual Metaphor as Theology: Leo the Great's Sermons on the Incarnation and the Arch Mosaics at S. Maria Maggiore", in Gesta 26, 83-91.

Spain 1979: “The Promised Blessing': The Iconography of the Mosaics of S. Maria Maggiore", in The Art Bulletin, 61, 518-540.

Steigerwald G. 2003: "Noch einmal: Zur Darstellung Jesu im Tempel am Triumphbogen von S. Maria Maggiore in Rom", Jahrbuch für Antike und Christentum 46, 74-83.

Tanner N.P. 1990: Decrees of the Ecumenical Councils, Vol. I, London.

Thérel M.L. 1962: "Une image de la Siylle sur l'arch triumphal de Sainte-Marie-Majeure à Rome”, Cahiers Archéologiques. Fin de l'antiquité et moyen âge 12, 153 171.

de Waal A. 1887: "Die apokryphen Evangelien in der alchristlichen Kunst”, Römische Quartalschrift, I*.

Warland R. 2003: "The Concept of Rome in Late Antiquity reflected in the Mosaics of S. Maria Maggiore in Rome", in Acta ad archaeologiam et artium historiam pertinentia, Vol. 17 (N.S. 3), Rome, 127-141.

Weis A. 1960: „Die Geburtsgeschichte Christi am Triumphogen von S. Maria Maggiore“, Das Münster 13, 73-88. Wellen G.A. 1961: Theotokos. Utrecht.

Wesche K.P. 1991: On the Person of Christ. The Christology of Emperor Justinian. Crestwood, New York. 
Wilpert J. 1917: Die römischen Mosaiken und Malereien der kirchlichen Bauten vom IV. - XIII. Jahrhundert Freiburg.

Wilpert J. 1931: „La proclamasione Efesina e i mosaici della basilica di S. Maria Maggiore“, in Analecta
Sacra Terraconensia 7, 197-213.

Wilpert J. - Schumacher W. 1976: Die römischen Mosaiken der kirchlichen Bauten vom VI.-XIII. Jahrhundert, Freiburg, Basel, Wien. 